\title{
Invited review: Changes in the dairy industry affecting dairy cattle health and welfare
}

\author{
H. W. Barkema, ${ }^{* 1}$ M. A. G. von Keyserlingk,† J. P. Kastelic, ${ }^{*}$ T. J. G. M. Lam, † C. Luby,§ J.-P. Roy,\# \\ S. J. LeBlanc,II G. P. Keefe,ף and D. F. Keltonll \\ ${ }^{*}$ Department of Production Animal Health, Faculty of Veterinary Medicine, University of Calgary, Calgary, AB T2N 4N1, Canada \\ †Animal Welfare Program, Faculty of Land and Food Systems, University of British Columbia, Vancouver, BC V6T 1Z4, Canada \\ ‡Department of Farm Animal Health, Faculty of Veterinary Medicine, Utrecht University, Utrecht 3508 TD, the Netherlands \\ §Department of Large Animal Clinical Sciences, Western College of Veterinary Medicine, University of Saskatchewan, Saskatoon, SK S7N 5B4, \\ Canada \\ \#Department of Clinical Sciences, Faculté de Médecine Vétérinaire, Université de Montréal, Saint-Hyacinthe, QC J2S 7C6, Canada \\ \|Department of Population Medicine, Ontario Veterinary College, University of Guelph, Guelph, ON N1G 2W1, Canada \\ IDepartment of Health Management, Atlantic Veterinary College, University of Prince Edward Island, Charlottetown, PE C1A 4P3, Canada
}

\section{ABSTRACT}

The dairy industry in the developed world has undergone profound changes over recent decades. In this paper, we present an overview of some of the most important recent changes in the dairy industry that affect health and welfare of dairy cows, as well as the science associated with these changes. Additionally, knowledge gaps are identified where research is needed to guide the dairy industry through changes that are occurring now or that we expect will occur in the future. The number of farms has decreased considerably, whereas herd size has increased. As a result, an increasing number of dairy farms depend on hired (nonfamily) labor. Regular professional communication and establishment of farm-specific protocols are essential to minimize human errors and ensure consistency of practices. Average milk production per cow has increased, partly because of improvements in nutrition and management but also because of genetic selection for milk production. Adoption of new technologies (e.g., automated calf feeders, cow activity monitors, and automated milking systems) is accelerating. However, utilization of the data and action lists that these systems generate for health and welfare of livestock is still largely unrealized, and more training of dairy farmers, their employees, and their advisors is necessary. Concurrently, to remain competitive and to preserve their social license to operate, farmers are increasingly required to adopt increased standards for food safety and biosecurity, become less reliant on the use of antimicrobials and hormones, and provide assurances regarding animal welfare. Partly because

Received January 23, 2015.

Accepted July 17, 2015.

${ }^{1}$ Corresponding author: barkema@ucalgary.ca of increasing herd size but also in response to animal welfare regulations in some countries, the proportion of dairy herds housed in tiestalls has decreased considerably. Although in some countries access to pasture is regulated, in countries that traditionally practiced seasonal grazing, fewer farmers let their dairy cows graze in the summer. The proportion of organic dairy farms has increased globally and, given the pressure to decrease the use of antimicrobials and hormones, conventional farms may be able to learn from well-managed organic farms. The possibilities of using milk for disease diagnostics and monitoring are considerable, and dairy herd improvement associations will continue to expand the number of tests offered to diagnose diseases and pregnancy. Genetic and genomic selection for increased resistance to disease offers substantial potential but requires collection of additional phenotypic data. There is every expectation that changes in the dairy industry will be further accentuated and additional novel technologies and different management practices will be adopted in the future.

Key words: herd size, antimicrobials, biosecurity, automated milking system, automated calf feeder

\section{INTRODUCTION}

Economic pressures, technological innovations, demographic shifts, consumer expectations, and an evolving regulatory framework have contributed to the impetus for changes in the global dairy industry. These changes have had, and will likely continue to have, profound effects on the health and welfare of dairy cows and on management practices and systems for dairy herds. This paper presents an overview of some of the most important recent changes in the dairy industry that affect health and welfare of dairy cows, as well as the science associated with these changes. Finally, we iden- 
tify knowledge gaps where research is needed to guide the dairy industry through changes that already are underway or that we predict will occur in the future.

Although the primary focus of this paper is the dairy industry in North America, Europe, Australia, and New Zealand, implications of the changes described herein will be relevant for the dairy industry in most developed and developing nations. Although we strive to minimize biases from our own professional and personal experiences, as well as cultural influences, we recognize that this no doubt influenced some of the arguments presented herein.

\section{HERD SIZE AND MILK PRICE}

The average size of dairy herds has continuously increased over recent decades in all developed countries (Figure 1). Concurrently, the number of dairy farms has decreased in most countries, with the exception of New Zealand, where the number of dairy farms has been stable since 2007, but given the 2 -fold increase in herd size compared with 1996, the national dairy herd has doubled since 1990 (DairyNZ, 2013; Figure 1). In the United States, the number of dairy farms decreased from 139,670 in 1995 to 49,331 in 2012 (USDA-NASS, 1999, 2013a). However, since 1995, the total US dairy herd decreased by only $2.5 \%\left(9.46 \times 10^{6}\right.$ versus 9.22 $\times 10^{6}$ cows in 1995 versus 2013, respectively; USDANASS, 1999, 2013b). Consequently, cows are increasingly managed in fewer, albeit larger, herds (Figure 2). In 2012 , the $32 \%$ of US dairy herds with $<30$ cows had $1.6 \%$ of the national herd, whereas the $1.3 \%$ of US herds with $>2,000$ cows had $33 \%$ of the national herd (Figure 2A). In Germany, the situation is similar, albeit less pronounced (Figure 2B). In New Zealand (Figure $2 \mathrm{C}$ ) and Denmark (Figure 2D), there is a paucity of small herds, although the proportion of cows in very large herds is also not very high. Notwithstanding, there are regional differences in herd sizes. For example, in the United States, dairy herds in the Southwest and West are much larger than those in the Upper Midwest and Northeast (USDA-NASS, 2013c). Similarly, dairy herds in the eastern states of Germany are considerably larger than those in the western states and particularly Bavaria (König et al., 2005). The increase in herd size is driven by economies of scale - the cost of production per unit decreases with an increasing herd size (Wolf, 2003; Wilson, 2011). The increase in average herd size has been less pronounced in countries with a supply management system (e.g., countries within the European Union until March 2015 and Canada; Richards and Jeffrey, 1997). Given that the supply-managed system in Canada is based on domestic consumption, total milk production in Canada increased from 74 to 78 million hectoliters from 1997 to 2014 (Canadian Dairy Information Centre, 2015), reflecting increased demand due to population growth. However, this increase in milk production in Canada has been achieved almost exclusively through increased milk production per cow, with cow numbers having declined by $13 \%$ since 2000 (Canadian Dairy Information Centre, 2015). Concurrently, the average Canadian dairy herd increased from 52 cows in 1996 to 79 cows in 2014 (Figure 1), again reflecting a reduction in the number of farms. These developments are mirrored in other countries that have a milk supply management system but are in contrast to countries that are not supply managed (included those that recently abandoned this system) and are subject to the fluctuations in world milk price (e.g., Australia, New Zealand, United States); in these cases, we see dramatic increases in herd size (Figure 1).

The association between herd size and health and welfare is complex and affected by many factors, including the managerial skills of the farmer, rate of herd expansion, facilities, training and experience of personnel, and the ratio of caretakers to animals. Although few studies have critically assessed effects of herd size on animal health and welfare, it appears that herd size does not have a consistent, predictable association with health or welfare. For instance, Chapinal et al. (2014a,b) provided evidence that larger farms in both the United States and China have a lower prevalence of lameness. However, herd-level and within-herd prevalence of infectious diseases such as Johne's disease, bovine tuberculosis, and Q-fever in general increase with increasing herd size (e.g., Anastácio et al., 2014; Doyle et al., 2014; Wolf et al., 2014a). This association may be confounded by recent herd expansion, including purchase and mixing of animals from multiple sources, rather than being an effect of herd size itself. However, mortality rates in US dairy herds increase with increasing herd size (Shahid et al., 2015). In contrast to herd size, increased milk production is often associated with decreased health of dairy cows. For example, the incidence of clinical mastitis, lameness, and other diseases may be increased in higher-producing dairy cows (Koeck et al., 2014). Partly due to a lack of large, valid data sets on health outcomes, there is limited literature on the level of milk yield as a risk factor for disease. However, a structured review (Ingvartsen et al., 2003) concluded that there was an association of milk yield with clinical mastitis but not with dystocia, retained placenta, metritis, or left-displaced abomasum. Those authors emphasized that the problems of confounding of the relationship of yield and disease are common and likely substantial in many studies, and that metabolic 
adaptation and immune function variables intervene in this relationship. Given that a substantial proportion of increased milk production is attributable to genetic selection (Koeck et al., 2014), we caution against trying to solve this problem by forcing lower milk production. Efforts should focus instead on understanding the impact of management on cow health and welfare (e.g., LeBlanc et al., 2006).

The profitability of dairy production is highly dependent on milk price. In most countries with a developed dairy industry (except those with supply management), the price paid to producers for milk is not regulated and consequently can be highly volatile, even over short intervals. Over the last 2 decades, many countries, such as Australia, Switzerland, and countries within the European Union, have abandoned supply management (quota) systems; consequently, given market pressures, these countries have often experienced fluctuating (typically declining) milk prices to align with global prices (e.g., Sinclair et al., 2014).

Decreases in milk price result in reduced profitability and ultimately cause one or both of the following reactions. Herd size may increase abruptly in an attempt to maintain cash flow (Sinclair et al., 2014) but might result in overstocking, thereby reducing access to primary resources by individual cows, which may diminish health or performance (of individual cows and eventually of the group or herd) and compromise animal welfare (see reviews by von Keyserlingk et al., 2009; von Keyserlingk and Weary, 2010). With reduced milk prices, farmers may also attempt to decrease costs by reducing the use of what they perceive as nonessential inputs or expenses that they have more discretion over, which may include veterinary service and participation in herd-monitoring programs, such as those provided by DHIA (e.g., Walter, 1995). However, Hare et al. (2004)

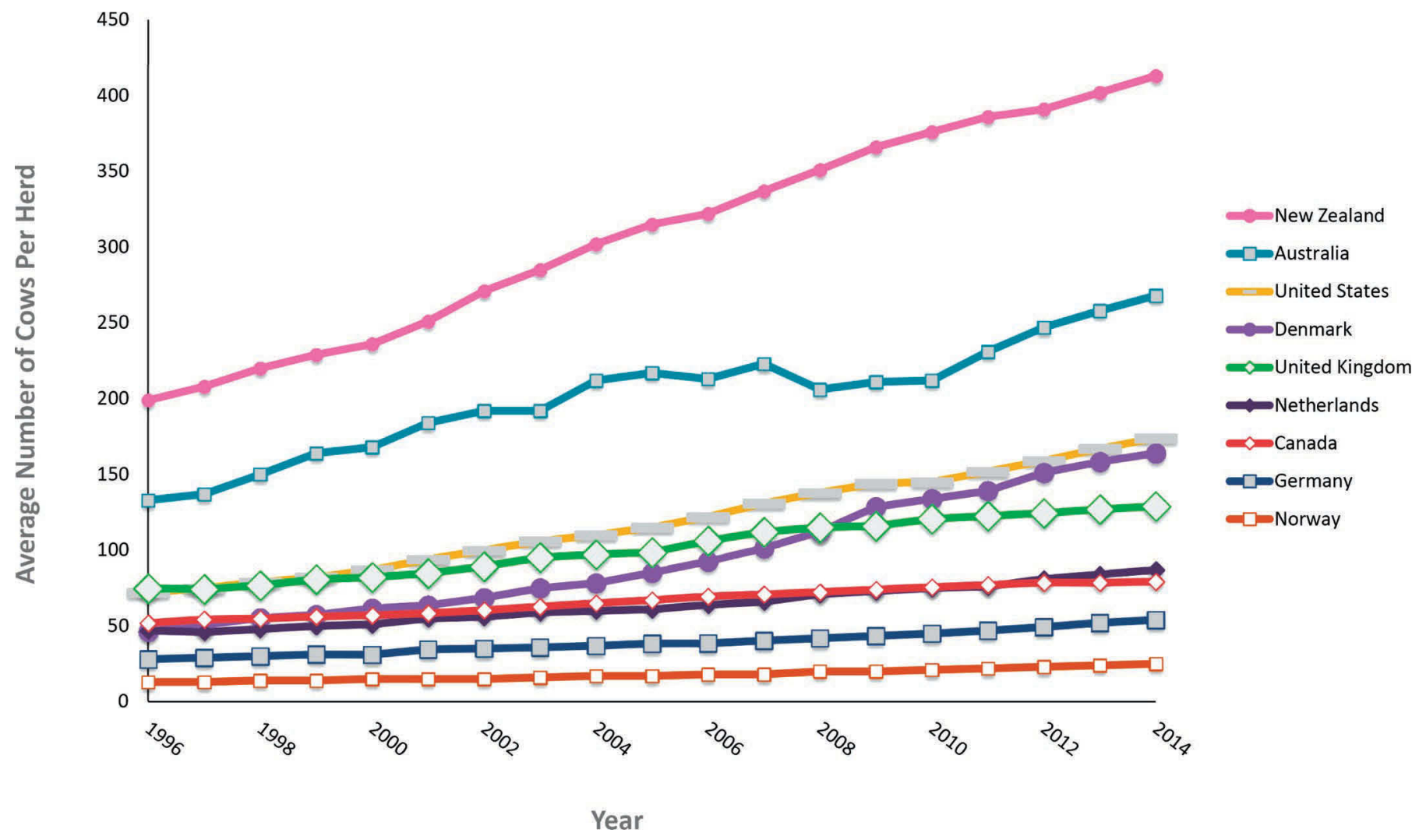

Figure 1. Average size of dairy cattle herds in selected countries. Data sources: New Zealand: DairyNZ, Hamilton (http://www.lic.co.nz/ lic_Publications.cfm); Australia: Dairy Australia (http://www.dairyaustralia.com.au/ /media/Documents/Stats\%20and\%20markets/In\%20 Focus/Australian\%20Dairy\%20Industry\%20In\%20Focus\%202014.pdf); United States: Economic Research Service/NASS, Washington, DC (http://www.ers.usda.gov/data-products/dairy-data.aspx); Denmark: Statistics Denmark (http://www.dst.dk/en); United Kingdom: DairyCo (http://dairy.ahdb.org.uk/resources-library/market-information/farming-data/distribution-by-size/\#.VdeqlrTfEdI); The Netherlands: CRV Jaarstatistieken (https://www.crv4all.nl/downloads/crv/jaarverslag/); Germany: Statistische Bundesamt, Mai Viehzählung (https://www. destatis.de/DE/); Canada: Canadian Dairy Information Center (http://www.dairyinfo.gc.ca); Norway: Statistics Norway (https://www.ssb.no/ en/). Color version available online. 
did not find an increase in termination of DHIA participation when the milk-to-feed price ratio decreased.

\section{FARM DEMOGRAPHICS}

The demographics of dairy farmers and other farm workers have changed in the last decades. The typical dairy farmer owning a farm in a developed country is well educated and knowledgeable about new technologies and has become more business-minded (Noordhuizen et al., 2008). Furthermore, due to increased herd size, fewer children per farm family, and less frequent involvement of adult children in the family farm, more farms in developed countries depend on nonfamily labor. In a study in Wisconsin in 2007, $<5 \%$ of farms with $<49$ cows had hired labor, whereas all herds with $>500$ cows had nonfamily workers (Harrison et al., 2009). Consequently, skilled farm labor is often in limited supply (e.g., Bewley et al., 2001; von Keyserlingk et al., 2013). Skill or ability differs considerably among farm workers, availability of competent laborers is often problematic (Winsten et al., 2010), and there is often rapid turnover (Hagevoort et al., 2013). Particularly in the United States, but also on larger dairy farms in Italy, New Zealand, Denmark, and Canada, foreign workers are common, creating additional challenges such as communication (Susanto et al., 2010; Schenker and Gunderson, 2013), which contributes to difficulties with human resources (Hagevoort et al., 2013). Insufficient training of farm workers has been argued by some to be the cause of lower detection of health problems and poor animal handling, calving management and milking technique (e.g., Gutierrez-Solano et al., 2011; Schuenemann et al., 2013), as well as poor health and safety conditions for farm workers (Hagevoort et al., 2013). Given that successful implementation of regular meetings, policy documents, and standard operating procedures have successfully addressed these issues in intensive care units of human hospitals (e.g., Sandahl et al., 2013), we strongly encourage a similar approach in the dairy industry, as has already been adopted on some larger US dairy operations. It is well established that when farm-specific treatment protocols are used, the frequency of errors decreases, treatments are applied with greater consistency and better rationale, and treatment outcomes can be more readily assessed (Raymond et al., 2006; Oliveira and Ruegg, 2014).

\section{ORGANIC DAIRY FARMING}

The proportion of dairy farms certified to produce organic milk has increased globally, currently ranging from $2 \%$ in Canada to $26 \%$ in Austria, whereas in Sweden, Denmark, and Switzerland, a considerable percentage of dairy farms produce organic milk (Figure 3). Although regulations for organic dairying differ among countries, broadly speaking, organic farms must consistently adhere to a strict set of regulations that differ in many ways from those on conventional farms.

Organic agriculture is based on agro-ecological principles, including promotion of naturalness (i.e., access to pasture, restrictions on amount of grain fed, increased interval from calving to removal of the calf, and no use of AI or embryo transfer; Marley et al., 2010). The extent to which these principles are enforced varies among countries and their certification agencies. For example, regulations for the European Union and the United States differ regarding antimicrobials for treatment of sick cattle. In the European Union, although a treated animal can remain in the herd, the duration of mandatory milk withdrawal for each antimicrobial must be doubled. In contrast, in the United States, cattle given antimicrobials are banned from re-entering the organic animal production system and must be removed from the herd (Zwald et al., 2004; Koopman et al., 2008). This regulation has effectively halted antimicrobial use within organic US dairy herds for either prevention or treatment of mastitis (Zwald et al., 2004), and homeopathic products are often used as an alternative therapy (although their efficacy is typically unknown; e.g., Ruegg, 2009).

Effects of restricted antimicrobial use on animal welfare within organic systems have not been well characterized (Marley et al., 2010). In the case of the antimicrobial example given above, some producers may elect to delay or withhold treatment, hoping that the cow recovers without intervention. Given the potential negative outcomes and associated welfare concerns when withholding treatment, we strongly encourage future work to evaluate the attitudes and practices of organic producers regarding care of sick cows. In addition, ongoing research that identifies alternative remedies that are effective and safe (according to standards similar to those used for conventional pharmaceuticals) but also comply with organic standards must continue to be a priority.

Studies that compare cow health on organic dairy farms and conventional farms have reported contradictory results. Improved health of cows on organic farms compared with conventional farms, particularly in relation to mastitis (e.g., Richert et al., 2013; Levison et al., 2015), lameness (e.g., Rutherford et al., 2009), and hock lesions (e.g., Rutherford et al., 2008; Bergman et al., 2014) has been reported by some, whereas other studies have reported no differences in mastitis incidence and SCC (Hovi et al., 2003; Fall and Emanuelson, 2009; Haskell et al., 2009; Lund and Algers, 2003) or ketosis (Richert et al., 2013). Cows on organic dairy 
farms have also been reported to have lower milk yields, higher SCC, and higher age at first calving compared with those on conventional farms (Roesch et al., 2005; Nauta et al., 2006). Management practices that are not necessarily associated with a specific production system will also likely affect many of these parameters (e.g., cow cleanliness, stall maintenance).

Given the numerous concerns regarding antimicrobials and hormonal treatments (see Council for Agricultural Science and Technology, 2012), conventional

A)

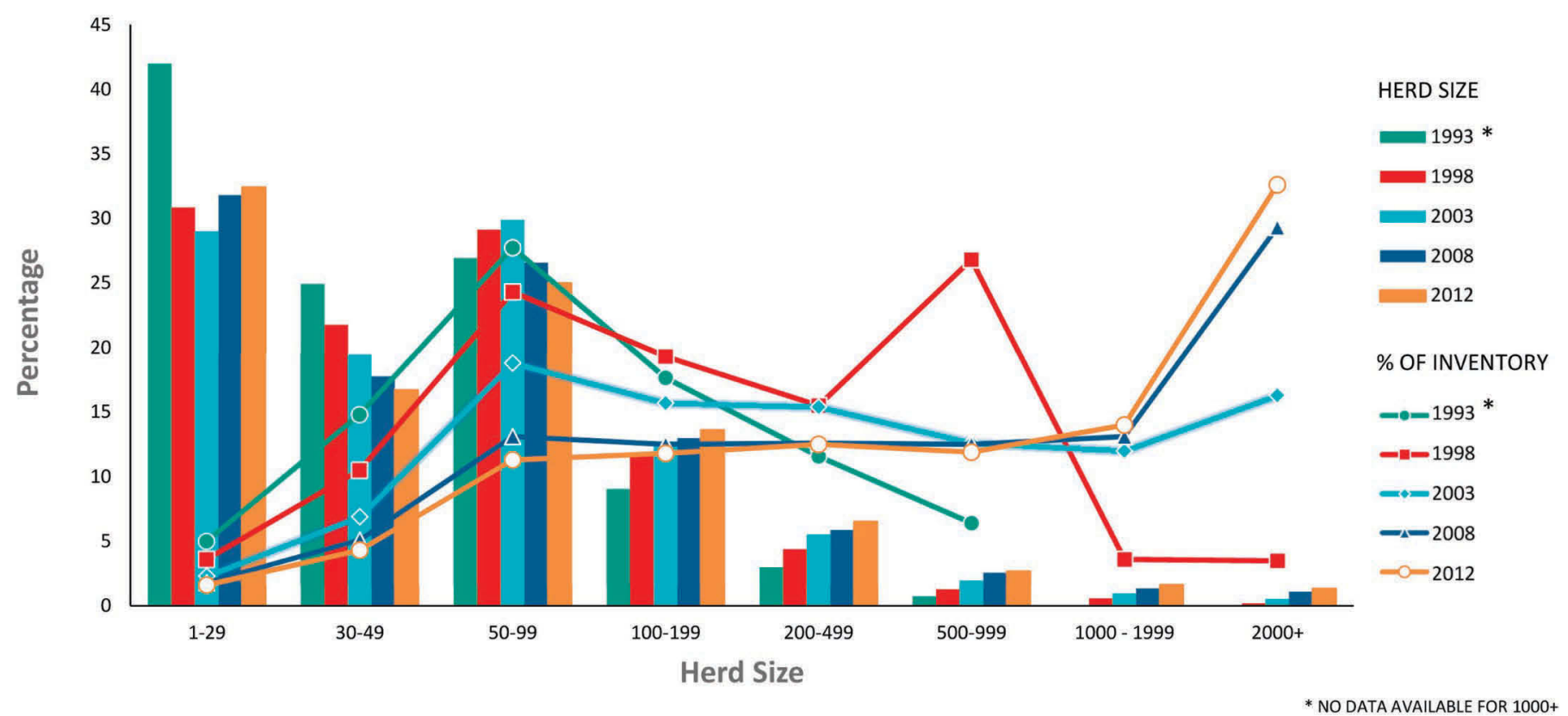

B)

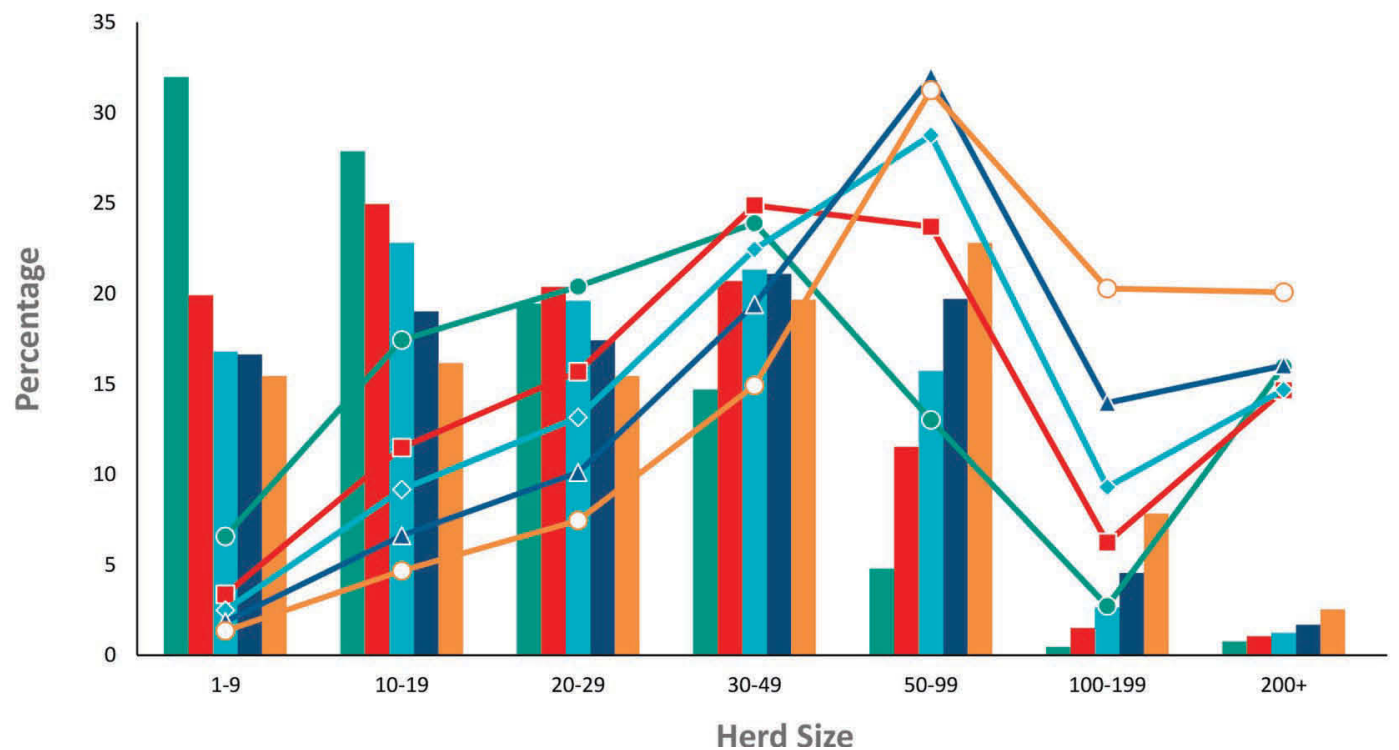

HERD SIZE

1992

1999

2003

2008

2012

$\%$ OF INVENTORY

- 1992

- 1999

$-2003$

$-\Delta-2008$

$-0-2012$

Figure 2. Distribution of dairy herd size and percentage of cows per herd size (\% of inventory) over the last 20 yr in the United States (A), Germany (B), New Zealand (C), and Denmark (D). Note: Herd size categories differ among the 4 countries. Color version available online. 
farms could gain valuable knowledge from well-managed organic farms. For instance, given that diseases such as mastitis continue to be a major problem on conventional dairy farms (e.g., Olde Riekerink et al., 2008), combined with the expectation of increasing pressure to limit the use of antimicrobials (Saini et al., 2012a), identifying organic farms with low disease rates and understanding their management practices could provide insights to enhance animal health on conventional farms.

C)

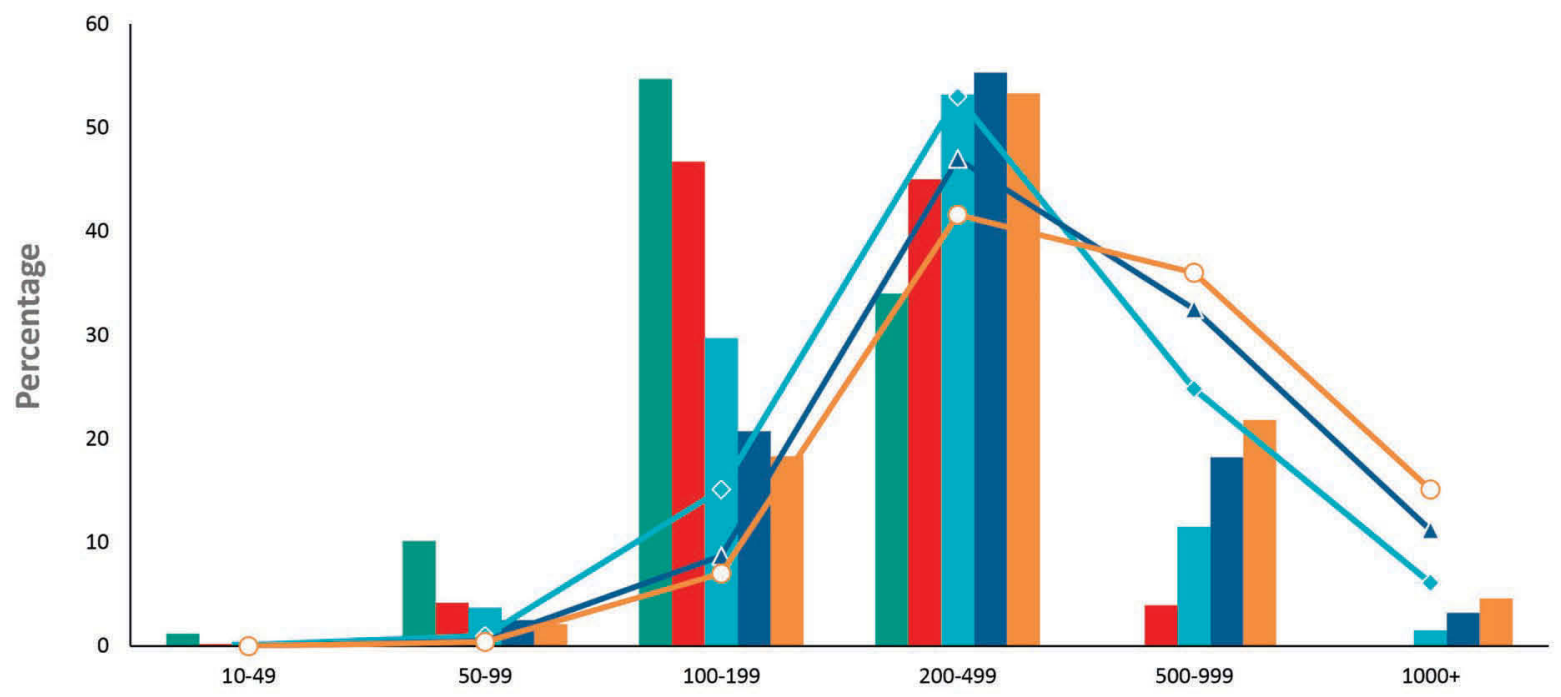

HERD SIZE

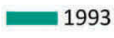

1998

2003

2008

2012

$\%$ OF INVENTORY

$-1993^{*}$

$-1998 *$

$=2003$

$-1008$

$-0-2012$

Herd Size

* NO DATA AVAILABLE

D)

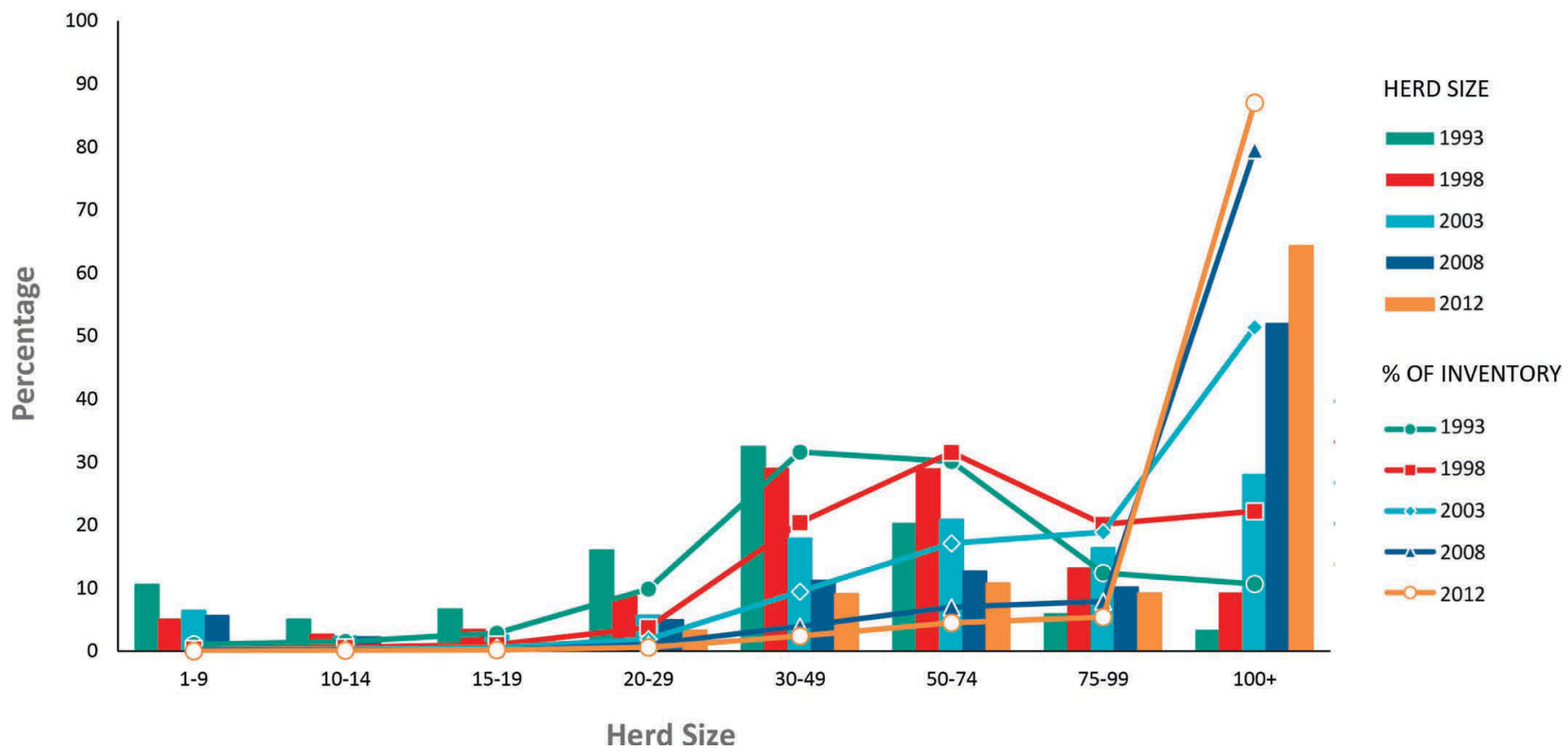

Figure 2 (Continued). Distribution of dairy herd size and percentage of cows per herd size (\% of inventory) over the last 20 yr in the United States (A), Germany (B), New Zealand (C), and Denmark (D). Note: Herd size categories differ among the 4 countries. Color version available online. 


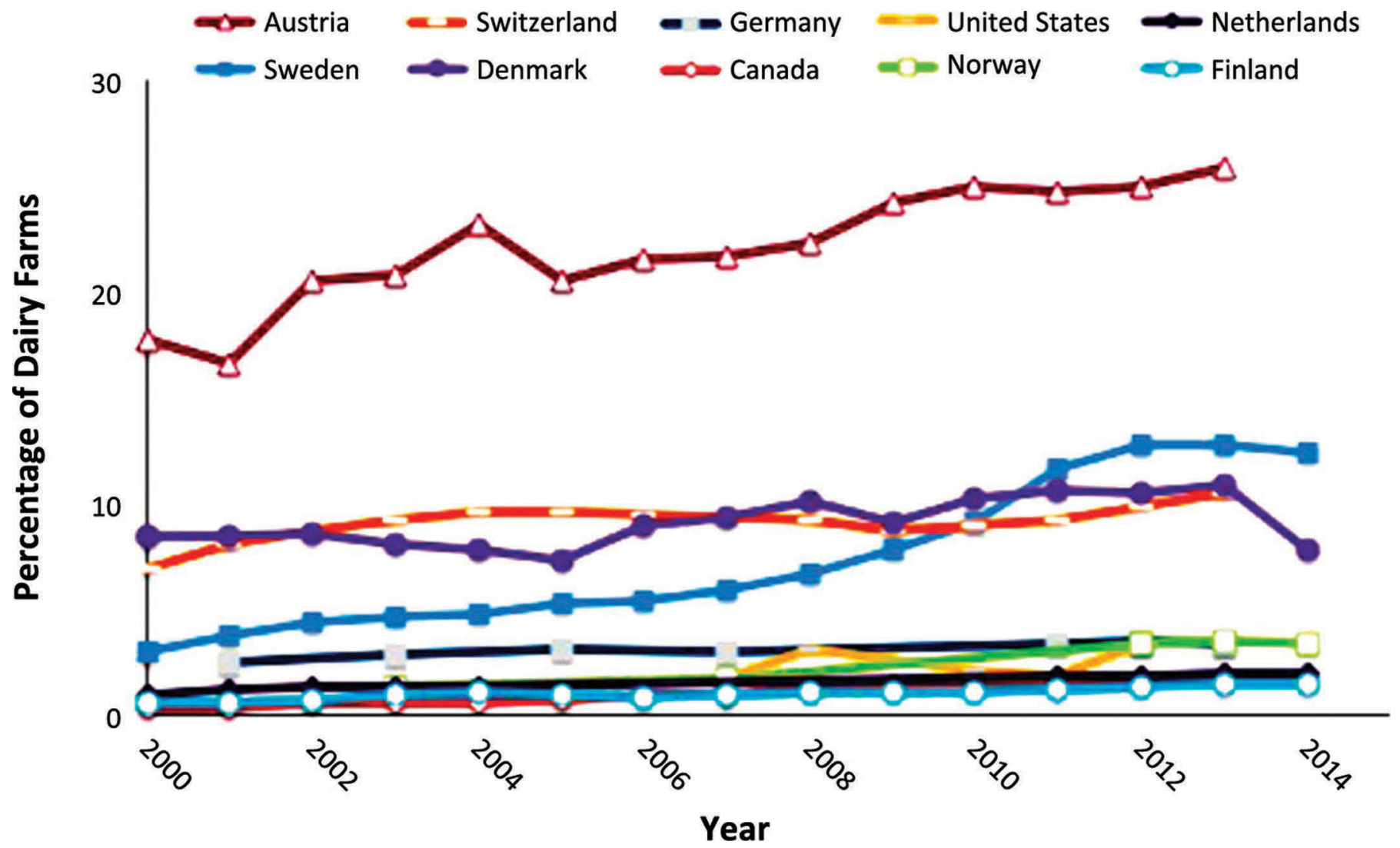

Figure 3. Percentage of organic dairy farms in selected countries. The list of countries is limited to those for which we were able to provide sufficient reliable data. Color version available online.

\section{ANIMAL WELFARE}

Consumers and citizens (influencing processors and retailers) have long-standing interests in the safety and quality of milk products (Drake, 2007); however, more recently, there has been increased interest in the care and housing of cows that produce milk and its associated products (von Keyserlingk et al., 2009). Belgian consumers rated animal welfare as the second most important priority (after food safety) when deciding what food to purchase (Vanhonacker et al., 2007, 2008). In a recently completed research needs assessment, animal welfare was rated as the top management issue by 1,025 dairy producers, industry advisors, and government dairy experts in Canada (Cathy Bauman, University of Guelph, unpublished data). Animal advocates have argued strongly for improved practices on farms, citing "lack of naturalness" and perceived cruelty as standard practices (Vanhonacker et al., 2008). These criticisms have resulted in a polarized debate and in many cases, entrenched positions by advocates and those representing the dairy industry (von Keyserlingk et al., 2013). Several issues, such as cow-calf separation shortly after calving (Ventura et al., 2013), tail docking (Weary et al., 2011), lack of access to pasture (Schuppli et al., 2014), dehorning and castration with insufficient anesthesia or analgesia (Vasseur et al., 2010), and individual housing of calves (Gaillard et al., 2014) are contentious issues, with stakeholders holding widely varying opinions regarding standard practices (von Keyserlingk et al., 2009). Furthermore, tail-docking was practiced on $48 \%$ of dairy farms in the United States (USDA, 2007) and in many herds in Canada, despite no proven benefits for udder health or milk quality (see review by Sutherland and Tucker, 2011) and formal opposition from the American Veterinary Medical Association (2014), the American Association of Bovine Practitioners (2010), and the Canadian Code of Practice for the Care and Handling of Dairy Cattle (National Farm Animal Care Council, 2009).

In northern climates, dairy cows are predominantly housed in tie- or freestall barns. Although there are regional differences in housing type, a significant but decreasing proportion of dairy herds are housed in tiestalls (USDA, 2007; Popescu et al., 2013; Table 1). Because dairy herds housed in tiestalls are consider- 
ably smaller than freestall-housed herds (e.g., Wolf et al., 2014a), the proportion of dairy cattle housed in freestalls is relatively larger than that in tiestalls. For example, although only $26 \%$ of Norwegian dairy barns were freestalls in 2014 (Table 1), this represented $42 \%$ of the dairy cows (Olav Østerås, TINE SA, Ås, Norway; personal communication). Housing systems for dairy cattle have come under increased scrutiny, particularly in northern Europe, including from critics internal and external to the dairy industry. For example, in 2 Norwegian studies, cows in freestall environments had better reproductive performance and lower incidence and prevalence of most diseases compared with cows housed in tiestalls (e.g., Valde et al., 1997; Simensen et al., 2010). In contrast, the apparent prevalence of lameness was lower in tiestalls compared with freestalls in Wisconsin (Cook, 2003; Cramer et al., 2009) and Norway (Sogstad et al., 2005). However, persons external to the dairy industry have also raised concerns regarding restriction of movement, including expression of social behaviors, combined with a desire for perceived naturalness (Boogaard et al., 2011; Popescu et al., 2013). Thus, it is not surprising that continued use of tiestall housing is being questioned in some countries. For example, building new tiestall housing in Norway was outlawed in 2004, with a complete ban of this housing type scheduled for 2023 (Simensen et al., 2010). Additionally, in the European Union, organic dairy farms have been prohibited from building tiestall barns since 2000 , and since 2010, dairy cows must be in loose-housing barns, with the exception of small herds (although the exact herd size cut-off for "small herds" was not defined; Swensson, 2008). The decline in proportion of tiestalls in North America is likely in large part a consequence of increased farm size, but we predict an even greater decline as restriction of movement becomes an issue. There is an expectation that, following measures implemented in Europe, at least some North American consumers would not support tiestall housing or complete confinement (Spooner et al., 2014). We recognize that systems that allow for greater degrees of freedom of movement (e.g., freestall, pasture) are not without welfare challenges. For instance, concerns regarding lameness have been reported for cows housed in zerograzing, freestall systems (e.g., US and Canada; von Keyserlingk et al., 2012) as well as under some grazing systems (e.g., Chile; Sepúlveda-Varas et al., 2014).

The move toward zero-grazing systems in many countries is being increasingly questioned (e.g., Schuppli et al., 2014). These questions are timely given the growing disconnect between current industry practices and consumer or citizen expectations (Te Velde et al., 2002); fewer than $5 \%$ of lactating cows within the United States are provided access to pasture (USDA, 2007). A growing body of literature shows that citizens associate pasture access with good welfare (reviewed in part by von Keyserlingk et al., 2013). Moreover, recent work has also shown benefits to lameness associated with access to pasture (Hernandez-Mendo et al., 2007; Chapinal et al., 2013). However, other experimental work has shown that cows have a strong preference for access to pasture during the night but remain indoors for the majority of the day (Legrand et al., 2009; Falk et al., 2012), when temperature and humidity are high (Charlton et al., 2013). Clearly, the issue of pasture access for lactating dairy cattle is not straightforward and is in need of further research.

Most dairy farmers, animal and dairy scientists, and many veterinarians have frequently argued that high levels of milk production and good health are clear evidence of high standards of welfare (von Keyserlingk et al., 2009). Not surprisingly, much research has focused on nutritional strategies to improve milk production and animal health. In contrast, members of the public frequently place emphasis on affective states (ability to feel pain and pleasure) and naturalness (the ability for an animal to live a reasonably natural life) (Fraser et al., 1997, 2013; Boogaard et al., 2011). Given the difference between the industry and society regarding priorities in animal welfare, it is not surprising that

Table 1. Percentage of dairy herds that have their adult cows housed in a tiestall barn in selected countries (empty cells reflect lack of reliable estimates)

\begin{tabular}{lcccc}
\hline Country $^{1}$ & $2000-2004$ & $2005-2008$ & $2009-2011$ & $2012-2014$ \\
\hline United States & 53 & 49 & 74 & 38 \\
Canada & & & 64 & 61 \\
Iceland & 86 & 74 & 52 & 74 \\
Norway & 81 & 76 & 76 & 69 \\
Sweden & 89 & 82 & 10 & 8 \\
Finland & 65 & 28 & 27 & 78 \\
Denmark & 18 & 13 & 79 & 78 \\
Netherlands & 36 & 82 & & \\
Germany & 87 & & & \\
Switzerland &
\end{tabular}

${ }^{1}$ The list of countries is limited to those for which we were able to provide sufficient reliable data. 
pain management is not consistently used for dehorning, castration, and removal of supernumerary teats in Canada and the United States (Hewson et al., 2007; USDA, 2007; Vasseur et al., 2010; Fajt et al., 2011) or for clinical mastitis or lameness (Leslie and PeterssonWolfe, 2012). Therefore, research and product development are essential to increase the availability and adoption of effective, approved, and affordable pain management methods for dairy cattle.

\section{CHANGING TECHNOLOGY}

The adoption of technology on dairy farms is accelerating (see review by Rutten et al., 2013), with profound implications for how cattle are housed and managed on dairy farms. For example, calves are now frequently fed using an automatic calf feeder (ACF) and cows milked using an automated milking system (AMS). In addition, many technologies have become broadly available, including pedometers or activity monitors for estrus detection, in-line sensors to determine milk quality, composition, and electrical conductivity characteristics of milk (e.g., Rutten et al., 2013), and the use of sexed semen (e.g., De Vries et al., 2008). There is tremendous potential for many of these technologies to improve health and welfare (e.g., calf health, lameness, and mastitis) and reproductive performance, as these tools are objective and have frequently been reported to identify animals needing attention in a more timely manner than is possible with human observation (Svensson and Jensen, 2007; de Mol et al., 2013; Rutten et al., 2013; Chanvallon et al., 2014). Further improvements in sensor technology, integration of data from multiple systems and, in particular, increased training of farmers, their personnel, and advisors to use sensorderived data will enable "precision dairy farming" to be implemented, potentially leading to more timely identification of animals requiring attention and ultimately increased farm profitability. The field of dairy technology, however, is just in its infancy, and although it clearly has tremendous potential, much research is needed to refine and improve technologies and develop validated interpretive cut-points, algorithms, and protocols for useful action based on the data.

Although most automated systems generate data and action lists, the utility of the information garnered from these data is largely unrealized, likely due, in part, to lack of training by dairy farmers and their advisors, including the herd veterinarian. Additionally, too often a new technology is brought to market before sufficient research, including validation, is done, let alone training of users and advisors. Another possible limitation that exacerbates failure to make use of these rich data sources is that various technologies typically do not "talk to each other," resulting in many herd health computer software systems failing to integrate data arising from various technologies.

\section{Automated Calf Feeders}

In a 2013 survey, 33 (21\%) of 154 larger dairy farms in Ontario, Canada, used an ACF to feed heifer calves (Progressive Dairy Operators, 2013). These systems allow for group housing, which reduces labor (Broom and Leaver, 1978), and enable delivery of milk via a nipple at volumes and frequencies that are more natural and that support faster growth (de Paula Vieira et al., 2008) and reduced sickness events (Godden et al., 2005). An additional benefit is generation of data regarding individual milk intake rate and frequency of feeding events that have promise for objectively monitoring calf health and growth (Borderas et al., 2009). However, more research is needed before we can rely exclusively on monitoring data for detection of disease in calves; consequently, routine observation of calves to assess health status remains essential (Borderas et al., 2008). Furthermore, there is recent evidence that social housing of calves may improve cognition (Gaillard et al., 2014). However, we caution against the use of large groups, particularly dynamic groups, as increased transmission of infectious disease in groups of greater than 8 calves has been reported (Losinger and Heinrichs, 1997; Svensson and Liberg, 2006; Engelbrecht Pedersen et al., 2009). Moreover, small groups of calves (e.g., 6 to 9) had improved growth rates and health compared with larger groups (12 to 18; Svensson and Liberg, 2006).

Despite evidence that all-in-all-out systems may further reduce some of the health risks associated with group housing (Engelbrecht Pedersen et al., 2009), many small farms may find it difficult to implement this practice. Average calf group size on commercial dairy farms is not well defined but likely variable (Endres, 2013). Furthermore, introduction of an ACF often results in challenges, potentially because of large dynamic group sizes (but also due to hygiene, air quality, ventilation, and so on; Ziegler and Chester-Jones, 2013). For example, increased intake of milk replacer in calves fed with an ACF will increase production of urine and feces, with consequences for bedding, cleaning, and ventilation. Given the proven benefits of providing calves more milk early in life (see review by Khan et al., 2011), additional research on optimal management of this is needed, including consideration of factors such as farm size. Of particular interest is the recent report that on 17 dairy farms in Alberta, Canada, infected with Mycobacterium avium ssp. paratuberculosis (MAP), $3 \%$ of calves were actively shedding the bacterium and on $52 \%$ of these farms, MAP-positive environmental 
samples were collected from calf pens (Wolf et al., 2015). Group housing of calves may therefore increase the risk of calf-to-calf transmission of MAP. However, the extent to which calf-to-calf transmission of MAP occurs in group-housed calves or is important in the ecology of Johne's disease still needs to be determined.

\section{Automated Milking Systems}

The first AMS units were installed in the Netherlands and in Ontario, Canada, in 1992 and 1999, respectively (de Koning, 2011). Worldwide, more than 25,000 dairy farms now use AMS, with the greatest adoption of this technology being in Denmark, Sweden, Iceland, and the Netherlands (Figure 4). In North America, the number of AMS is also increasing but largely driven by increased installations in Canada; as of 2014, approximately 5\% of Canadian dairy farms used this system (Figure 4), although adoption of AMS is still relatively low in the United States, likely due to lower milk prices and labor costs. Recent reports that AMS units can also be incorporated into pasture-based systems (Lyons et al., 2014) may result in increased adoption in countries such as Ireland, Australia, and New Zealand. However, Lyons et al. (2014) argued that additional research is needed to improve management strategies to increase milking frequency when AMS systems are used for cows on pasture.

Potential challenges include the ability of the AMS system to generate cow-level data that may prompt producers to consider less-frequent milk recording or even withdrawing from a DHI program. This may in turn reduce availability of data for genetic evaluations or performance benchmarking that is publically available or in other instances is restricted (and proprietary) to individual equipment providers. Although AMS and other in-line milk analysis tools and the associated software provide frequent and detailed streams of data at the cow level, in their current iterations they may be less useful for herd-level synthesis and analysis of data (e.g., Garcia et al., 2014). Consequently, producers and farm staff may not routinely use these data when mak-

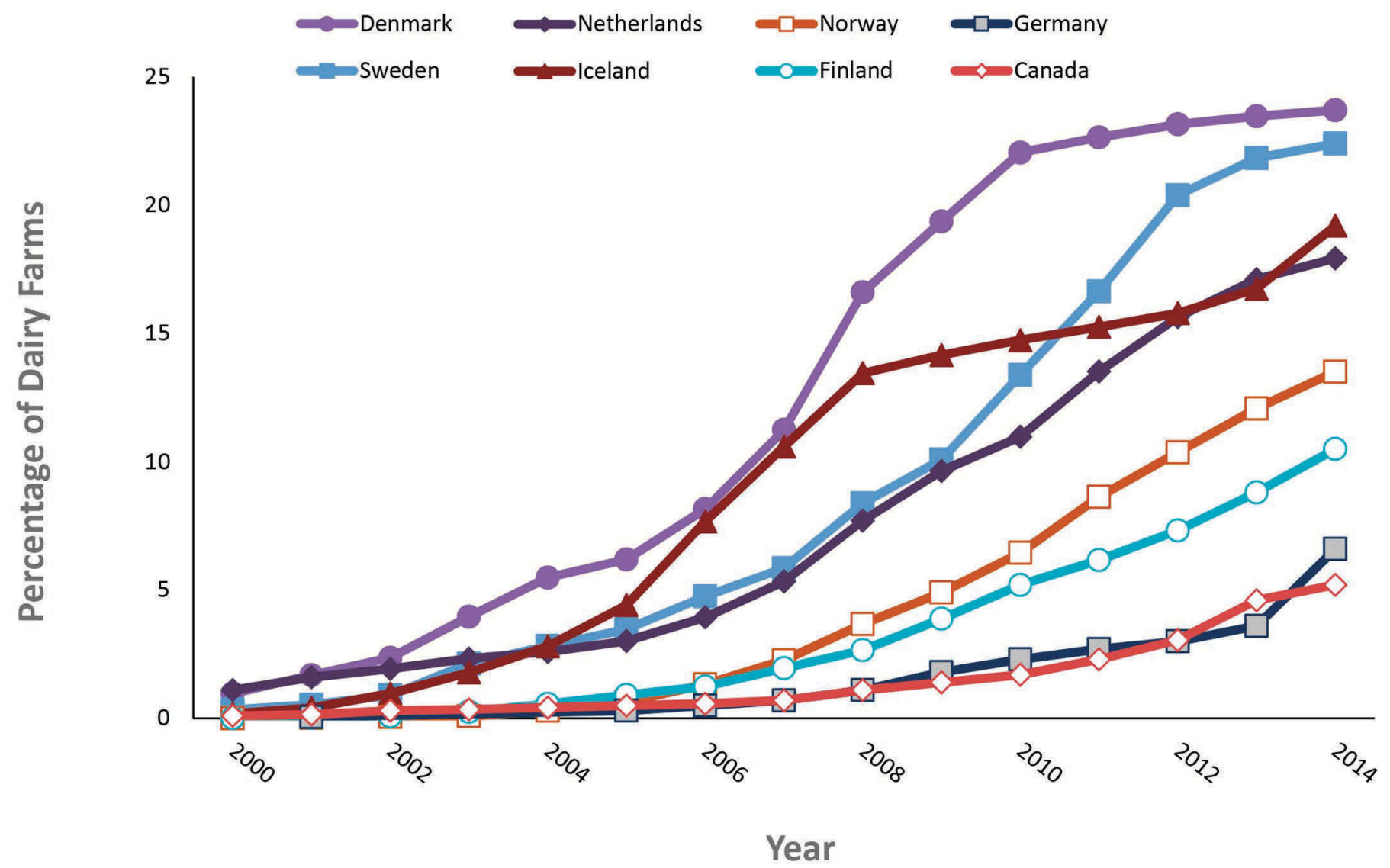

Figure 4. Percentage of dairy farms using an automated milking system in selected countries. The list of countries is limited to those for which we were able to provide sufficient reliable data. Color version available online. 
ing management decisions. This would be particularly worrisome, given the benefits associated with evidencebased decision-making (e.g., Chapinal et al., 2014b).

Implementation of an AMS does not eliminate udder health problems; in contrast, it has been associated with increased transmission of pathogens, which can increase bulk tank SCC (Hovinen and Pyörälä, 2011). The use of one milking unit by 50 to 60 lactating cattle, which usually exceeds the number of cows milked per unit in a conventional system, has great potential for transmission of pathogens. The prevalence of Streptococcus agalactiae intramammary infections is higher in AMS herds, with a clear difference among AMS models (Radtke et al., 2012; Bennedsgaard and Katholm, 2013). With appropriate management, animal health and welfare can, however, be excellent in herds with AMS (see review by Jacobs and Siegford, 2012).

\section{ANTIMICROBIALS}

Antimicrobial resistance (AMR) in bacteria is an important public health hazard (Prescott, 2014). Furthermore, human medical organizations frequently blame livestock industries for increased AMR (e.g., World Health Organization, 2012; Ontario Medical Association, 2013). There is some merit in their accusations, as noted by Prescott (2014) and other recent evidence. Livestock can be reservoirs of resistance genes; for example, those associated with production of extended-spectrum $\beta$-lactamases in Enterobacteriaceae, which can be transferred to humans (Fey et al., 2000). For example, ceftiofur (an extended-spectrum cephalosporin) commonly used to treat dairy cattle, including systemic administration in cows with coliform mastitis (Wagner and Erskine, 2006), has been suggested as a possible driver for an increase in extended-spectrum $\beta$-lactamase resistance (Grove-White and Murray, 2009). Escherichia coli resistant to extended-spectrum $\beta$-lactamases have also been isolated in milk from dairy cattle in Europe (MARAN-2008, 2009). However, although cloxacillin, an antimicrobial similar to methicillin/oxacillin that is extensively used for dry cow therapy (Saini et al., 2012a), was predicted to select for methicillin-resistant Staphylococcus aureus (MRSA), the latter have only rarely been isolated from milk samples (Saini et al., 2012c; Tenhagen et al., 2014).

Although antimicrobial use in human medicine arguably contributes at least as much to AMR as corresponding use in the livestock sector (Bywater and Casewell, 2000; Morley et al., 2005), it is important that livestock industries, including veterinary practitioners, proactively apply principles of prudent and judicious use of antimicrobials and generally aim to decrease and regulate the use of antimicrobials, particularly those with potential relevance to human health (American Veterinary Medical Association, 2009). There is great need to preserve the ability to rationally use antimicrobials (e.g., for treatment of clinical disease); however, the livestock industry must also make every effort to minimize AMR. In discussions with regulators and legislators, it is important that the dairy industry differentiates its common uses of antimicrobials from those in other industries, which may include much broader use of pharmaceuticals of high importance to human health, or (until recently) prolonged, low-level use of antimicrobials in feeds, which is much more likely to promote development of AMR than short-term use for individual-animal therapy (Saini et al., 2012b). Some countries have already begun to increase regulations directed at antimicrobial usage in agriculture. For example, in the Canadian province of Québec, antibiotics are only dispensed to farmers under veterinary prescription or supervision (Sibbald, 2012). Also, following the announcement by the Dutch Minister of Agriculture that antibiotic usage by the livestock industry in the Netherlands must decline, the prophylactic use of antimicrobials was forbidden (Bos et al., 2013), and overall use was reduced by $56 \%$ from 2007 to 2012 (Speksnijder et al., 2015). A pivotal step that led to achieving this goal was the Dutch dairy industry stopping blanket dry-cow treatment (a long-standing cornerstone of udder health management) and replacing it with selective dry-cow treatment. Given the reduction in antimicrobial use already achieved, Dutch animal industries have revised their target and now aim to achieve a $70 \%$ reduction (of the original 2010 baseline) by 2015 (Speksnijder et al., 2015). Notwithstanding decreased antimicrobial use, how this ban affects udder health (and arguably animal welfare) in lactating dairy cattle in the Netherlands remains to be determined; not surprisingly, the first evidence indicates that even in low SCC cows, there has been an increase in the incidence of clinical mastitis (Scherpenzeel et al., 2014).

\section{HORMONES}

Protocols for synchronization of estrus and ovulation with timed AI (e.g., CoSynch, OvSynch, and PreSynch) are widely used in many countries (e.g., Bisinotto et al., 2014; Wiltbank and Pursley, 2014). Although most of the products used in these programs are approved for use in lactating cattle, their use in some protocols and in combinations are extra-label. Moreover, the use of hormones in lactating cows, especially products that regulate the reproductive system, might be subject to heavy criticism (despite a lack of evidence of risk to humans) if the public understood the extent to which these technologies are used by the dairy indus- 
try (Burke and Verkerk, 2010; von Keyserlingk et al., 2013). Also of interest is a recent study on the clinical and ethical values of veterinarians in the UK regarding the use of hormones to manage dairy cow reproduction. Respondents indicated that on farms where no effort was made to address underlying management problems limiting reproductive performance, long-term routine use of timed AI protocols was judged "unacceptable" by practitioners (Higgins et al., 2013). Therefore, it is plausible that there will be increasing pressure to limit the use of synchronization programs. Automated activity monitoring systems for estrus detection may be able to achieve reproductive performance similar to that of synchronization programs using 2 to 5 injections per insemination (Neves et al., 2012; Fricke et al., 2014; Rutten et al., 2014), but these systems may not eliminate the need for hormonal interventions in at least a minority of cows to achieve reasonable goals for reproductive performance.

If the use of hormones to manage reproduction is curtailed, producers will be required to either rely on visual estrus detection or make use of automated technologies that identify cows in estrus. Structural impediments to estrus expression, including total confinement in tiestalls and slippery floors, will also need to be addressed. Research efforts identifying and optimizing the application of alternative management practices, such as activity and rumination monitors, temperature sensors, and in-line milk progesterone tests that identify cows in estrus, have resulted in reasonably accurate systems (Saint-Dizier and Chastant-Mallard, 2012), but more work is needed to validate these systems.

\section{BIOSECURITY}

North America and countries in southern Europe are well behind northern Europe with regard to implementing infectious disease control programs within the dairy industry. Northern European countries are officially free of several infectious diseases, including leptospirosis, bovine leukosis, and tuberculosis; furthermore, control programs are in place for Johne's disease, infectious bovine rhinotracheitis (IBR), bovine viral diarrhea (BVD), salmonellosis, and neosporosis (Barkema et al., 2009). This tremendous achievement is largely attributed to routine practices of requesting diagnostic test results when purchasing cattle, embryos, or semen, and the use of milk-based tests for monitoring herds for diseases with substantial deleterious effects on production and longevity (Gottschau et al., 1990; Bitsch and Rønsholt, 1995; van Schaik et al., 2002; Rossmanith et al., 2010). However, in most other parts of the world, progress has been much slower.
Unfortunately, several "new" infectious diseases are threatening the global dairy industry (e.g., Schmallenberg virus; Beer et al., 2013). Countries, including those that are currently free of specific infectious diseases, such as Norway and Sweden for BVD and Johne's disease (Valle et al., 2005; Barkema et al., 2010), Western Australia for Johne's disease (Kennedy, 2012), and several regions in Europe for IBR (Raaperi et al., 2014), will need to protect themselves against introduction of these diseases. It is well established that national disease control programs can be profitable for the dairy industry as a whole, as well as for individual dairy farmers (Valle et al., 2005; Wolf et al., 2014b).

In many countries, the dairy industry is increasingly focusing on control of infectious diseases and biosecurity (Sahlström et al., 2014; Sarrazin et al., 2014); however, success is dependent upon participation of a large majority of milk producers in these programs. Participation will be maximized if both individual producers and the dairy industry as a whole perceive benefits in return for the time and effort invested. As dairy veterinarians are the most trusted advisors of dairy producers, their support will be crucial for successful implementation of these programs (Young et al., 2010; Jansen and Lam, 2012). National and regional dairy organizations will have important roles in how infectious disease and biosecurity programs will be implemented and which specific diseases must be targeted, based on objective data from prevalence studies, cost-benefit analyses, and potential for success. Much of the knowledge required to develop testing and control programs for many diseases is already available. Some of these programs have been validated and are currently in use in northern European countries (e.g., Makoschey et al., 2010). Ideally, these programs allow for visitors to the farm (Barkema et al., 2009), as openness will increase public trust (Deimel et al., 2008).

Second to cattle movements between farms (Gates et al., 2013), visitors play an important role in transmission of pathogens among farms. For example, in the early stages of the 2001 foot-and-mouth disease (FMD) outbreak in the Netherlands, a veterinary practitioner likely transmitted the infection from one farm to another, resulting in destruction of a substantial proportion of the cattle herds in that practice (Bouma et al., 2003). Diseases that are endemic (e.g., IBR, BVD, and Johne's disease) can also be transmitted from farm to farm if precautions are not adequate (Barkema et al., 2009). North American dairy farms have no recent experience with devastating infectious disease outbreaks such as FMD. Consequently, many dairy producers do not perceive visitors as an important risk factor for introduction of infections (Young et al., 2010) and may 
be resistant to implementing appropriate biosecurity measures. In contrast, in western Europe, outbreaks of infectious diseases, such as tuberculosis, Q-fever, FMD, bluetongue, and recently Schmallenberg virus, have highlighted the importance of biosecurity (Bouma et al., 2003; van Engelen et al., 2014; Veldhuis et al., 2014). Although implementation of on-farm biosecurity measures is still far from optimal on these farms (Sayers et al., 2013), it is now common practice on western European dairy farms, where the risk of transmission of infectious diseases (e.g., Schmallenberg virus) is high, that visitors are routinely provided with coveralls and boots (Sahlström et al., 2014; Sarrazin et al., 2014), a practice that is not prevalent on many North American dairy farms (USDA, 2010).

\section{ROUTINE DIAGNOSTIC SERVICES}

Several milk-borne bacteria and viruses not considered causes of mastitis but of importance in cow health or milk safety are shed in milk or antibodies against these pathogens can be detected in the milk (e.g., Gao et al., 2009). Examples include MAP, Salmonella, BVD virus, Neospora caninum, leptospirosis, and Coxiella burnetii (the cause of Q-fever). Although an ELISA test for MAP antibodies is already in use (e.g., Lavers et al., 2014), the utility of milk-based tests for other human pathogens potentially present in milk requires further evaluation.

In many European countries, disease control programs have included detection of DNA or antibodies in milk (e.g., Houe et al., 2006). In most countries, laboratory testing for animal diseases was, until recently, usually done by regional and national diagnostic laboratories (e.g., Edmondson et al., 2007). However, DHI organizations increasingly offer testing of milk samples for bovine leukosis, mastitis pathogens, Johne's disease, BVD, IBR, leptospirosis, and Neospora caninum, thereby efficiently providing targeted or comprehensive data to producers and veterinarians for use in disease prevention decisions.

Current DHI organizations have infrastructure that efficiently collects, transports, and tests milk samples, as well as identifies, collects, and summarizes data regarding cattle on the farm. Milk-recording organizations are potentially capable of processing large numbers of samples and large amounts of data as part of infectious disease monitoring and prevention programs. It is therefore expected that the DHI organizations will expand their range of laboratory diagnostic services.

The possibilities of using milk for disease diagnostics and monitoring are considerable (van Doormaal, 2011). Beyond generating herd management information, as the number of herds that use DHIA samples for disease diagnostics increases, we see substantial benefits in being able to access reliable regional data regarding the prevalence and impact of various diseases; clearly, this could be very valuable for developing disease control policies.

\section{GENETIC AND SEX SELECTION}

Quantitative genetics has had a critical role in increasing milk production of dairy cattle (Butler, 2013). In contrast, genetics as an approach to disease control is an emerging discipline (Miglior et al., 2012). Because good evidence exists for genetic influences on susceptibility to diseases and infections in dairy cattle, in addition to disease prevention and control practices, breeding for genetic resistance to infectious diseases has become more attractive (Berry et al., 2011). Genetic markers have been identified for common disorders such as mastitis (Haugaard et al., 2013), lameness (van der Spek et al., 2015), and infertility (Butler, 2013), and for infectious diseases such as Johne's disease (Alpay et al., 2014) and bovine leukemia virus (Forletti et al., 2013). The widespread adoption of milk somatic cell counting has enabled numerous studies on quantitative genetics of udder health (e.g., de Haas et al., 2003). Recently, adaptive immune response phenotypes of Canadian dairy cattle were evaluated and found to be associated with fertility parameters and the incidence of clinical mastitis, metritis, displaced abomasum, and retained fetal membranes (Thompson-Crispi et al., 2012). Based on these studies, genomic breeding indices based on high immune response have been developed (Thompson-Crispi et al., 2014a,b). Although genetic improvement of disease resistance is slow, results of genetic selection are long lasting. Consequently, animal selection based on marker-assisted breeding might lead to cattle populations with enhanced disease resistance.

Genetic selection for improved udder health is now included in selection indices in most countries (Miglior et al., 2012), with the strongest emphasis on udder health in Scandinavia (Miglior et al., 2012). The combination of a direct measure (e.g., clinical mastitis incidence), in conjunction with SCC as an indirect measure, is used for the breeding value estimation in Canada, France, Denmark, Finland, and Sweden, whereas Norway uses only clinical mastitis data (Heringstad et al., 1999; Svendsen and A-Ranberg, 2000; Miglior et al., 2014). Other countries select for udder health using indirect measures, such as SCC, udder conformation, and milking speed (Miglior et al., 2012).

Although quantitative genetic studies have demonstrated that genetics plays an important role in sus- 
ceptibility to disease and infections, the genetic basis of these diseases is not well known. The estimated heritability of susceptibility to mastitis ranges from 0.01 to 0.42 (Nash et al., 2000), indicating that part of the variability in response to exposure in dairy cattle is due to genetics. Multiple recent studies also suggest that susceptibility for most diseases in dairy cattle is multior polygenic (e.g., Detilleux, 2009). Furthermore, many nongenetic variables contribute to disease risk (e.g., environmental factors and milking hygiene for mastitis). To date, however, there has been little congruence between different genetic and genomic studies on the same diseases. We believe this is due to (1) differences in the definitions of case and control, especially given multiple stages of the disease (e.g., clinical vs. subclinical disease, test-positive vs. clinical disease); (2) variation in phenotypic data recorded (observation, laboratory culture, or ELISA) and lack of large representative data sets with standardized and validated disease recording; and (3) variation in pathogens and their genotypes.

The potential for genetic selection using genomics is high. There is, however, currently no information concerning susceptibility of daughters of most AI sires for diseases other than mastitis. Notwithstanding, data collected in large studies such as the National Cohort of Dairy Farms of Canadian Bovine Mastitis Research Network (Reyher et al., 2011), the Canadian Cow Comfort study (Zaffino Heyerhoff et al., 2014), the Dutch Udder Health Centre (Lam et al., 2013), and data collected in the Scandinavian cattle databases (e.g., Lind et al., 2012) provide excellent opportunities to perform genetic studies. Those sires that have a decreased or increased proportion of daughters with disease problems can be identified and their genomes can be studied, with the long-term goal to decrease susceptibility to these diseases.

Sexed semen is used for AI in approximately $5 \%$ of the inseminations of dairy cattle in the United States (Seidel, 2014) and has shown to be economically beneficial (Chebel et al., 2010). Although the conception rate using sexed semen is considerably lower than that achieved with nonsexed semen (Norman et al., 2010), genetic progress is faster in herds that use sexed semen (De Vries et al., 2008). Additional benefits include increased availability of young stock, thereby facilitating faster rates of herd expansion (De Vries et al., 2008).

Given the growing concerns regarding the fate of dairy bull calves in North America (von Keyserlingk et al., 2009, 2013), using sexed semen must include consideration of the fate of any surplus females if supply were to exceed demand for replacement heifers. The dairy industry, particularly in countries where dairy calves play a lesser role in terms of meat production, is encouraged to consider alternative higher-welfare rearing systems for these "surplus" animals, regardless of sex. One approach would be to use sexed dairy semen on sufficient animals with the highest genetic merit to generate herd replacements and to use beef semen on the remaining herd, thus creating high-quality replacement heifers, as well as stock that is of greater value for use as a meat animal.

Finally, the adoption of high-production breeds such as the Holstein-Friesian adapted to temperate climates, without consideration for the animals' natural ability to cope with diseases and thermal challenges typical of extreme climates, such as the hot dry climates in many parts of the United States or in tropical or subtropical regions around the world, may lead to compromised welfare and reduced production (von Keyserlingk et al., 2013; von Keyserlingk and Hötzel, 2015). We encourage more research into alternative breeds or lines within breeds that allow for better resistance to high ambient temperatures and to diseases that are prevalent in (sub) tropical regions, perhaps complemented by research on effective heat abatement for these regions. This selection should lead to higher levels of milk production and better animal welfare.

\section{CONCLUSIONS}

The dairy industry in the developed world has undergone profound changes over recent decades. Additional changes in production practices that affect animal health and welfare seem inevitable, particularly given the societal concerns outlined herein, such as animal welfare and antibiotic resistance. These concerns, coupled with the notion that greater inclusion of societal input will be needed if dairy farmers are to retain their social license to operate, will likely affect the profitability of the dairy herd. The challenge facing the dairy industry is to balance those decisions and practices that may provide short-term economic gains but may also be associated with long-term risks regarding sustainability. How these pressures will translate into practice, and the speed at which they are voluntarily incorporated (or enforced), is difficult to predict (von Keyserlingk and Hötzel, 2015). However, the direction of these evolutionary forces on the dairy industry seems clear. Clearly, risks to the dairy industry can be reduced if dairy farmers proactively respond to these changes, for instance, by increasing their efforts to increase biosecurity and decrease the use of antimicrobials and hormones, while concurrently providing assurances of high standards of animal welfare. Increased adoption of technologies will enable farmers to have access to rich data sources that can aid in further improving animal 
health and welfare. However, to achieve these goals, farmers and their advisors must be trained in the use of data acquisition and interpretation and in use of the action lists that these technologies generate. Genetic and genomic selection for increased resistance to disease offers substantial potential but requires additional phenotypic data.

\section{ACKNOWLEDGMENTS}

The authors are grateful to Neil Petreny (CanWest DHI Guelph, Canada), and John Prescott (University of Guelph), Murray Jelinski (University of Saskatchewan), Jan Lievaart (Charles Sturt University, Wagga Wagga, Australia), Nancy Charlton (DeLaval Inc., Peterborough, Canada), Jan Willem Hesselink (Utrecht University), Hubert Karreman (Bovinity Health, Narvon, PA), Hiemke Knijn (CRV, Arnhem, the Netherlands), Réjean Bouchard (Dairy Farmers of Canada, Ottawa, Canada), Theo Lam (GD Deventer, Deventer, the Netherlands), and Andrew Hammermeister (Organic Agriculture Center of Canada, Truro, Canada) for reviewing previous versions of this manuscript and providing valuable suggestions, and to Pierre Doyle (Agriculture and Agri-Food Canada, Ottawa, Canada), Louwrens van Keulen (CRV Holding BV, Arnhem, the Netherlands), Martina Dötzl (Statistics Austria, Vienna, Austria), Lars Erik Ruud (Hedmark University College, Blæstad, Norway), Uffe Lauritsen (Danish Cattle Federation, Aarhus, Denmark), Snorri Sigurdsson (Knowledge Center for Agriculture, Aarhus, Denmark), Ilka Klaas (University of Copenhagen, Copenhagen, Denmark), Elizabeth Berry (DairyCo, Kenilworth, UK), Michael Miller (USDA-NASS, Washington, DC), Roger Hoskin (USDA-ERS, Washington, DC), Jonas Lichtenhahn (Swiss Statistics, Neuchâtel, Switzerland), Sylvia Ivemeyer (University of Kassel, Witxenhausen Germany), Robert Wolf (University of Calgary), Håkan Landin (Swedish Dairy Association, Hede, Sweden), Torkel Ekman (Swedish University of Agricultural Sciences, Uppsala, Sweden), Troels Kristensen (Aarhus University, Aarhus, University), Olav Østerås (TINE SA, Ås, Norway), Hannu Saloniemi (University of Helsinki, Helsinki, Finland), Bart van den Borne (University of Bern, Bern, Switzerland), Kerstin Barth (Thünen Institute of Organic Farming, Westerau, Germany), and Jason Lombard (USDA-APHIS-VS-CEAH, Fort Collins, CO) for providing data for Table 1 and Figures 2 to 4. Herman Barkema and Marina von Keyserlingk are funded through the NSERC Industrial Research Chair Program and associated industrial partners in the areas of infectious diseases and animal welfare of dairy cattle, respectively.

\section{REFERENCES}

Alpay, F., Y. Zare, M. H. Kamalludin, X. Huang, X. Shi, G. E. Shook, M. T. Collins, and B. W. Kirkpatrick. 2014. Genome-wide association study of susceptibility to infection by Mycobacterium avium subspecies paratuberculosis in Holstein cattle. PLoS ONE 9:e111704.

American Association of Bovine Practitioners. 2010. AABP Position statement-Tail docking. Accessed July 12, 2015. http://www. aabp.org/resources/aabp_position_statements/aabp_tail_ docking-3.13.10.pdf

American Veterinary Medical Association. 2009. Discussions of the Antimicrobial Use Task Force. Accessed July 12, 2015. https:// www.avma.org/KB/Resources/Reports/Documents/autf_final_ report.pdf.

American Veterinary Medical Association. 2014. Literature review on the welfare implications of tail docking of cattle. Accessed July 12 , 2015. https://www.avma.org/KB/Resources/LiteratureReviews/ Documents/tail_docking_cattle_bgnd.pdf.

Anastácio, S., N. Carolino, K. Sidi-Boumedine, and G. J. da Silva. 2014. Q fever dairy herd status determination based on serological and molecular analysis of bulk tank milk. Transbound. Emerg. Dis. http://dx.doi.org/10.1111/tbed.12275. In press.

Barkema, H. W., M. J. Green, A. J. Bradley, and R. N. Zadoks. 2009 Invited review: The role of contagious disease in udder health. J. Dairy Sci. 92:4717-4729.

Barkema, H. W., J. W. Hesselink, S. L. B. McKenna, G. Benedictus, and H. Groenendaal. 2010. Global prevalence and economics of infection with Mycobacterium avium ssp. paratuberculosis in ruminants. Chapter 2, pages 10-21 in Paratuberculosis: Organism, Disease, Control. M. A. Behr and D. M. Collins, ed. CAB International, Wallingford, UK.

Beer, M., F. J. Conraths, and W. H. van der Poel. 2013. 'Schmallenberg virus'-A novel orthobunyavirus emerging in Europe. Epidemiol. Infect. 141:1-8.

Bennedsgaard, T., and J. Katholm. 2013. Real-time PCR for mastitis pathogens in bulk tank milk samples and herd characteristics in Danish dairy herds. Page 18 in Proc. 29th NKVet Symp., Reykjavik, Iceland. The Nordik Committee for Veterinary Scientific Cooperation, Helsinki, Finland.

Bergman, M. A., R. M. Richert, K. M. Cicconi-Hogan, M. J. Gamroth, Y. H. Schukken, K. E. Stiglbauer, and P. L. Ruegg. 2014. Comparison of selected animal observations and management practices used to assess welfare of calves and adult dairy cows on organic and conventional dairy farms. J. Dairy Sci. 97:4269-4280.

Berry, D. P., M. L. Bermingham, M. Good, and S. J. More. 2011. Genetics of animal health and disease in cattle. Ir. Vet. J. 31:64-65.

Bewley, J., R. W. Palmer, and D. B. Jackson-Smith. 2001. An overview of experiences of Wisconsin dairy farmers who modernized their operations. J. Dairy Sci. 84:717-729.

Bisinotto, R. S., E. S. Ribeiro, and J. E. Santos. 2014. Synchronisation of ovulation for management of reproduction in dairy cows. Animal 8:151-159.

Bitsch, V., and L. Rønsholt. 1995. Control of bovine viral diarrhea virus infection without vaccines. Vet. Clin. North Am. Food Anim. Pract. 11:627-640.

Boogaard, B. K., B. B. Bock, S. J. Oosting, J. S. C. Wiskerke, and A. J. van der Zijpp. 2011. Social acceptance of dairy farming: The ambivalence between the two faces of modernity. J. Agric. Environ. Ethics 24:259-282.

Borderas, T. F., A. M. de Passillé, and J. Rushen. 2008. Behavior of dairy calves after a low dose of bacterial endotoxin. J. Anim. Sci. 86:2920-2927.

Borderas, T. F., J. Rushen, M. A. G. von Keyserlingk, and A. M. de Passillé. 2009. Automated measurement of changes in feeding behavior of milk-fed calves associated with illness. J. Dairy Sci. 92:4549-4554.

Bos, M. E. H., F. J. Taverne, I. M. van Geijlswijk, J. W. Mouton, D. J. Mevius, and D. J. J. Heederink. 2013. Consumption of antimicrobials in pigs, veal calves and broilers in The Netherlands: 
Quantitative results of nationwide collection of data in 2011. PLoS ONE 8:e77525.

Bouma, A., A. R. W. Elbers, A. Dekker, A. de Koeijer, C. Bartels, P. Vellema, P. van der Wal, E. M. A. van Rooij, F. M. Pluimers, and M. C. M. de Jong. 2003. The foot-and-mouth disease epidemic in The Netherlands in 2001. Prev. Vet. Med. 57:155-166.

Broom, D. M., and J. D. Leaver. 1978. Effects of group rearing or partial isolation on later social behaviour of calves. Anim. Behav. 26:1255-1263.

Burke, C. R., and G. A. Verkerk. 2010. The development of reproductive management practices in New Zealand: What will the future hold in a consumer-focused, environmentally-conscious, exportdriven marketplace? Soc. Reprod. Fertil. Suppl. 67:341-355.

Butler, S. T. 2013. Genetic control of reproduction in dairy cows. Reprod. Fertil. Dev. 26:1-11.

Bywater, R. J., and M. W. Casewell. 2000. An assessment of the impact of antibiotic resistance in different bacterial species and of the contribution of animal sources to resistance in human infections. J. Antimicrob. Chemother. 46:639-645.

Canadian Dairy Information Centre. 2015. Dairy facts and figures. Accessed July 12, 2015. www.dairyinfo.gc.ca.

Chanvallon, A., S. Coyral-Castel, J. Gatien, J. M. Lamy, D. Ribaud, C. Allain, P. Clément, and P. Salvetti. 2014. Comparison of three devices for the automated detection of estrus in dairy cows. Theriogenology 82:734-741.

Chapinal, N., A. K. Barrientos, M. A. G. von Keyserlingk, E. Galo, and D. M. Weary. 2013. Herd-level risk factors for lameness in freestall farms in the northeastern United States and California. J. Dairy Sci. 96:318-328.

Chapinal, N., Y. Liang, D. M. Weary, Y. Wang, and M. A. G. von Keyserlingk. 2014a. Risk factors for lameness and hock injuries in Holstein herds in China. J. Dairy Sci. 97:4309-4316.

Chapinal, N., D. M. Weary, L. Collins, and M. A. G. von Keyserlingk. 2014b. Lameness and hock injuries improve on farms participating in an assessment program. Vet. J. 202:646-648.

Charlton, G. L., S. M. Rutter, M. East, and L. A. Sinclair. 2013. The motivation of dairy cows for access to pasture. J. Dairy Sci. 96:4387-4396.

Chebel, R. C., F. S. Guagnini, J. E. Santos, J. P. Fetrow, and J. R. Lima. 2010. Sex-sorted semen for dairy heifers: effects on reproductive and lactational performances. J. Dairy Sci. 93:2496-2507.

Cook, N. B. 2003. Prevalence of lameness among dairy cattle in Wisconsin as a function of housing type and stall surface. J. Am. Vet. Med. Assoc. 223:1324-1328.

Council for Agricultural Science and Technology. 2012. The direct relationship between animal health and food safety outcomes. CAST Commentary QTA2012-1. Accessed July 12, 2015. http:// www.cast-science.org/publications/?the_direct_relationship_ between_animal_health_and_food_safety_outcomes\&show=prod uct\&productID $=155971$.

Cramer, G., K. D. Lissemore, C. L. Guard, K. E. Leslie, and D. F. Kelton. 2009. Herd-level risk factors for seven different foot lesions in Ontario Holstein cattle housed in tie stalls or free stalls. J. Dairy Sci. 92:1404-1411.

Dairy NZ. 2013. New Zealand dairy statistics 2012-2013. Accessed July 12 , 2015. http://www.lic.co.nz/user/file/DAIRY\%20 STATISTICS\%202012-13-WEB.pdf.

de Haas, Y., H. W. Barkema, Y. H. Schukken, and R. F. Veerkamp. 2003. Genetic associations for pathogen-specific clinical mastitis and patterns of peaks in somatic cell count. Anim. Sci. 77:187-195.

de Koning, C. J. A. M. 2011. Milking machines | Robotic milking. Pages 952-958 in Encyclopedia of Dairy Sciences. 2nd ed. J. W. Fuquay, ed. Academic Press, San Diego, CA.

de Mol, R. M., G. Andre, E. J. B. Bleumer, J. T. N. van der Werf, Y. de Haas, and C. G. van Reenen. 2013. Applicability of day-to-day variation in behavior for the automated detection of lameness in dairy cows. J. Dairy Sci. 96:3703-3712.

de Paula Vieira, A., V. Guesdon, A. M. B. de Passillé, M. A. G. von Keyserlingk, and D. M. Weary. 2008. Behavioural indicators of hunger in dairy calves. Appl. Anim. Behav. Sci. 109:180-189.
De Vries, A., M. Overton, J. Fetrow, K. Leslie, S. Eicker, and G. Rogers. 2008. Exploring the impact of sexed semen on the structure of the dairy industry. J. Dairy Sci. 91:847-856.

Deimel, M., M. Frentrup, and L. Theuvsen. 2008. Transparency in food supply chains: Empirical results from German pig and dairy production. J. Chain Netw. Sci. 8:21-32.

Detilleux, J. C. 2009. Genetic factors affecting susceptibility to udder pathogens. Vet. Microbiol. 134:157-164.

Doyle, L. P., A. W. Gordon, D. A. Abernethy, and K. Stevens. 2014 Bovine tuberculosis in Northern Ireland: Risk factors associated with time from post-outbreak test to subsequent herd breakdown. Prev. Vet. Med. 116:47-55.

Drake, M. A. 2007. Invited review: Sensory analysis of dairy foods. J. Dairy Sci. 90:4925-4937.

Edmondson, M. A., M. D. Givens, P. H. Walz, J. A. Gard, D. A Stringfellow, and R. L. Carson. 2007. Comparison of tests for detection of bovine viral diarrhea virus in diagnostic samples. J. Vet. Diagn. Invest. 19:376-381.

Endres, M. I. 2013. Management and housing of automated calf feeders in the Midwest US. Pages 97-100 in Proc. Precision Dairy Conf. and Expo, Rochester, MN. Accessed Jul. 12, 2015. http://www.precisiondairyfarming.com/2015/wp-content/ uploads/2015/08/2013-Precision-Dairy-Proceedings.pdf.

Engelbrecht Pedersen, R., J. Tind Sørensen, F. Skjøth, J. Hindhede, and T. Rousing Nielsen. 2009. How milk-fed dairy calves perform in stable versus dynamic groups. Livest. Sci. 121:215-218.

Fajt, V. R., S. A. Wagner, and B. Norby. 2011. Analgesic drug administration and attitudes about analgesia in cattle among bovine practitioners in the United States. J. Am. Vet. Med. Assoc. 238:755-767.

Falk, A. C., D. M. Weary, C. Winckler, and M. A. G. von Keyserlingk. 2012. Preference for pasture versus freestall housing by dairy cattle when stall availability indoors is reduced. J. Dairy Sci. 95:6409 6415 .

Fall, N., and U. Emanuelson. 2009. Milk yield, udder health and reproductive performance in Swedish organic and conventional dairy herds. J. Dairy Res. 76:402-410.

Fey, P. D., T. J. Safranek, M. E. Rupp, E. F. Dunne, E. Ribot, P. C. Iwen, P. A. Bradford, F. J. Angulo, and S. H. Hinrichs. 2000. Ceftriaxone-resistant Salmonella infection acquired by a child from cattle. N. Engl. J. Med. 342:1242-1249.

Forletti, A., M. A. Juliarena, C. Ceriani, A. F. Amadio, E. Esteban, and S. E. Gutiérrez. 2013. Identification of cattle carrying alleles associated with resistance and susceptibility to the bovine leukemia virus progression by real-time PCR. Res. Vet. Sci. 95:991-995.

Fraser, D., I. J. H. Duncan, S. A. Edwards, T. Grandin, N. G. Gregory, V. Guyonnet, P. H. Hemsworth, S. M. Huertas, J. M. Huzzey, D. J. Mellor, J. A. Mench, M. K. Špinka, and H. R. Whay. 2013. General Principles for the welfare of animals in production systems: The underlying science and its application. Vet. J. 198:19-27.

Fraser, D., D. M. Weary, E. A. Pajor, and B. N. Milligan. 1997. A scientific conception of animal welfare that reflects ethical concerns. Anim. Welf. 6:187-205.

Fricke, P. M., J. O. Giordano, A. Valenza, G. Lopes Jr., M. C. Amundson, and P. D. Carvalho. 2014. Reproductive performance of lactating dairy cows managed for first service using timed artificial insemination with or without detection of estrus using an activitymonitoring system. J. Dairy Sci. 97:2771-2781.

Gaillard, C., R. K. Meagher, M. A. G. von Keyserlingk, and D. M. Weary. 2014. Social housing improves dairy calves' performance in two cognitive tests. PLoS ONE 9:e90205.

Gao, A., J. Odumeru, M. Raymond, S. Hendrick, T. Duffield, and L. Mutharia. 2009. Comparison of milk culture, direct and nested polymerase chain reaction (PCR) with fecal culture based on samples from dairy herds infected with Mycobacterium avium ssp. paratuberculosis. Can. J. Vet. Res. 73:58-64.

Garcia, E., I. Klaas, J. M. Amigo, R. Bro, and C. Enevoldsen. 2014 Lameness detection challenges in automated milking systems addressed with partial least squares discriminant analysis. J. Dairy Sci. 97:7476-7486. 
Gates, M. C., M. E. Woolhouse, G. J. Gunn, and R. W. Humphry. 2013. Relative associations of cattle movements, local spread, and biosecurity with bovine viral diarrhoea virus (BVDV) seropositivity in beef and dairy herds. Prev. Vet. Med. 112:285-295.

Godden, S. M., J. P. Fetrow, J. M. Feirtag, L. R. Green, and S. J. Wells. 2005. Economic analysis of feeding pasteurized nonsaleable milk versus conventional milk replacer to dairy calves. J. Am. Vet. Med. Assoc. 226:1547-1554.

Gottschau, A., P. Willeberg, C. E. Franti, and J. C. Flensburg. 1990 The effect of a control program for enzootic bovine leukosis. Changes in herd prevalence in Denmark, 1969-1978. Am. J. Epidemiol. 131:356-364.

Grove-White, D., and R. Murray. 2009. Use of antimicrobials. Vet. Rec. 164:727.

Gutierrez-Solano, C., A. Ceballos-Marquez, and Y. H. Schukken. 2011. Bilingual trainings for milkers in New York State: A success for quality milk. Pages 191-196 in Udder Health and Communication. H. Hogeveen and T. J. G. M. Lam, ed. Wageningen Acad. Publ., Wageningen, the Netherlands.

Hagevoort, G. R., D. I. Douphrate, and S. J. Reynolds. 2013. A review of health and safety leadership and managerial practices on modern dairy farms. J. Agromedicine 18:265-273.

Hare, E., H. D. Norman, and J. R. Wright. 2004. Duration of herd participation in dairy herd improvement milk recording in the United States. J. Dairy Sci. 87:2743-2747.

Harrison, J., S. Lloyd, and T. O'Kane. 2009. Overview of immigrant workers on Wisconsin dairy farms. Program on Agricultural Technology Studies- Briefing no 1. Accessed July 12, 2015. http:// www.agroecology.wisc.edu/courses/agroecology-702/materials/11justice/harrison-et-al-2009.pdf.

Haskell, M. J., F. M. Langford, M. C. Jack, L. Sherwood, A. B. Lawrence, and K. M. D. Rutherford. 2009. The effect of organic status and management practices on somatic cell counts on UK dairy farms. J. Dairy Sci. 92:3775-3780.

Haugaard, K., L. Tusell, P. Perez, D. Gianola, A. C. Whist, and B. Heringstad. 2013. Prediction of clinical mastitis outcomes within and between environments using whole-genome markers. J. Dairy Sci. 96:3986-3993.

Heringstad, B., G. Klemetsdal, and J. Ruane. 1999. Clinical mastitis in Norwegian cattle: Frequency, variance components, and genetic correlation with protein yield. J. Dairy Sci. 82:1325-1330.

Hernandez-Mendo, O., M. A. G. von Keyserlingk, D. Veira, and D. M. Weary. 2007. Effects of pasture on lameness in dairy cows. J. Dairy Sci. 90:1209-1214.

Hewson, C. J., I. R. Dohoo, K. A. Lemke, and H. W. Barkema. 2007. Canadian veterinarians' use of analgesics in cattle, pigs, and horses in 2004 and 2005. Can. Vet. J. 48:155-164.

Higgins, H. M., E. Ferguson, R. F. Smith, and M. J. Green. 2013. Using hormones to manage dairy cow fertility: The clinical and ethical beliefs of veterinary practitioners. PLoS ONE 8:e62993.

Houe, H., A. Lindberg, and V. Moennig. 2006. Test strategies in bovine viral diarrhea virus control and eradication campaigns in Europe. J. Vet. Diagn. Invest. 18:427-436.

Hovi, M., A. Sundrum, and S. M. Thamsborg. 2003. Animal health and welfare in organic livestock production in Europe: Current state and future challenges. Livest. Prod. Sci. 80:41-53.

Hovinen, M., and S. Pyörälä. 2011. Invited review: Udder health of dairy cows in automatic milking. J. Dairy Sci. 94:547-562.

Ingvartsen, K. L., R. J. Dewhurst, and N. C. Friggens. 2003. On the relationship between lactational performance and health: Is it yield or metabolic imbalance that cause production diseases in dairy cattle? A position paper. Livest. Prod. Sci. 83:277-308.

Jacobs, J. A., and J. M. Siegford. 2012. Invited review: The impact of automatic milking systems on dairy cow management, behavior, health, and welfare. J. Dairy Sci. 95:2227-2247.

Jansen, J., and T. J. G. M. Lam. 2012. The role of communication in improving udder health. Vet. Clin. North Am. Food Anim. Pract. $28: 363-379$.

Kennedy, D. J. 2012. Controlling Johne's disease - Learning from the past 15 years. Proc. 11th Int. Colloq. Paratuberculosis, Sydney,
Australia. International Association for Paratuberculosis, Madison, WI.

Khan, M. A., D. M. Weary, and M. A. G. von Keyserlingk. 2011. Invited review: Effects of milk ration on solid feed intake, weaning and performance in dairy heifers. J. Dairy Sci. 94:1071-1081.

Koeck, A., S. Loker, F. Miglior, D. F. Kelton, J. Jamrozik, and F. S. Schenkel. 2014. Genetic relationships of clinical mastitis, cystic ovaries, and lameness with milk yield and somatic cell score in first-lactation Canadian Holsteins. J. Dairy Sci. 97:5806-5813.

König, S., G. Dietl, I. Reader, and H. H. Swalve. 2005. Genetic relationships for dairy performance between large-scale and smallscale farm conditions. J. Dairy Sci. 88:4087-4096.

Koopman, R., M. Ganter, and M. Link. 2008. Veterinary treatment in organic husbandry. Pages 56-59 in Proc. 2nd Scientific Conference of the International Society of Organic Agricultural Research, June 16-20, Modena, Italy. International Society of Organic Agriculture Research, Trenthorst, Germany.

Lam, T. J. G. M., B. H. P. van den Borne, J. Jansen, K. Huijps, J. C. L. van Veersen, G. van Schaik, and H. Hogeveen. 2013. Improving bovine udder health: A national mastitis control program in the Netherlands. J. Dairy Sci. 96:1301-1311.

Lavers, C. J., H. W. Barkema, I. R. Dohoo, S. L. B. McKenna, and G. P. Keefe. 2014. Evaluation of milk ELISA for detection of $M y-$ cobacterium avium subspecies paratuberculosis in dairy herds and association with within-herd prevalence. J. Dairy Sci. 97:299-309.

LeBlanc, S. J., K. D. Lissemore, D. F. Kelton, T. F. Duffield, and K. E. Leslie. 2006. Major advances in disease prevention in dairy cattle. J. Dairy Sci. 89:1267-1279.

Legrand, A. L., M. A. G. von Keyserlingk, and D. M. Weary. 2009 Preference and usage of pasture versus free-stall housing by lactating dairy cattle. J. Dairy Sci. 92:3651-3658.

Leslie, K. E., and C. S. Petersson-Wolfe. 2012. Assessment and management of pain in dairy cows with clinical mastitis. Vet. Clin North Am. Food Anim. Pract. 28:289-305.

Levison, L. J., E. K. Miller-Cushon, A. L. Tucker, R. Bergeron, K. E. Leslie, H. W. Barkema, and T. J. DeVries. 2015. Incidence rate of pathogen-specific clinical mastitis on organic and conventional Canadian dairy farms. J. Dairy Sci. http://dx.doi.org/10.3168/ jds.2015-9809

Lind, A., P. T. Thomsen, A. K. Ersbøll, M. N. Espetvedt, C. Wolff, S Rintakoski, and H. Houe. 2012. Validation of Nordic dairy cattle disease recording databases - Completeness for locomotor disorders. Prev. Vet. Med. 107:204-213.

Losinger, W. C., and A. J. Heinrichs. 1997. Management practices associated with high mortality among preweaned dairy heifers. J. Dairy Res. 64:1-11.

Lund, V., and B. Algers. 2003. Research on animal health and welfare in organic farming-A literature review. Livest. Prod. Sci $80: 55-68$.

Lyons, N. A., K. L. Kerrisk, and S. C. Garcia. 2014. Milking frequency management in pasture-based automatic milking systems: A review. Livest. Sci. 159:102-116.

Makoschey, B., P. Franken, J. M. Mars, E. Dubois, C. Schroeder, J. Thiry, M. Alvarez, K. Rypuła, S. Cavirani, I. Arnaiz, J. Y. Houtain, P. Bartak, J. Brownlie, G. Wolf, G. Meyer, W. Klees, M. Beer, V. Moennig, and E. Thiry. 2010. IBR and BVD control: The key to successful herd management. Berl. Munch. Tierarztl. Wochenschr. 123:519-521.

MARAN-2008. 2009. MARAN-2008-Monitoring of antimicrobial resistance and antibiotic usage in animals in the Netherlands in 2008. Accessed July 12, 2015. http://www.cvi.wur.nl/NR/rdonlyres/DDA15856-1179-4CAB-BAC6-28C4728ACA03/110563/ MARAN 2008 definitief corrected.pdf.

Marley, C. L., R. F. Weller, M. Neale, D. C. J. Main, S. Roderick, and R. Keatinge. 2010. Aligning health and welfare principles and practice in organic dairy systems: A review. Animal 4:259-271.

Miglior, F., J. Chesnais, and B. J. Van Doormaal. 2012. Genetic improvement: A major component of increased dairy farm profitability. Invited Presentation at 38th ICAR Biennial Session held in Cork, Ireland. ICAR Technical Series. International Committee for Animal Recording, Rome, Italy. 
Miglior, F., A. Koeck, G. Kistemaker, and B. J. Van Doormaal. 2014. A new index for mastitis resistance. Accessed July 12 , 2015. http://www.cdn.ca/Articles/GEBMAR2014/DCBGC\%20 Report_mastitis\%20-\%20FINAL.pdf.

Morley, P. S., M. D. Apley, T. E. Besser, D. P. Burney, P. J. FedorkaCray, M. G. Papich, J. L. Traub-Dargatz, and J. S. Weese. 2005. Antimicrobial drug use in veterinary medicine. J. Vet. Intern. Med. 19:617-629.

Nash, D. L., G. W. Rogers, J. B. Cooper, G. L. Hargrove, J. F. Keown, and L. B. Hansen. 2000. Heritability of clinical mastitis incidence and relationships with sire transmitting abilities for somatic cell score, udder type traits, productive life, and protein yield. J. Dairy Sci. 83:2350-2360.

National Farm Animal Care Council. 2009. Code of practice for the care and handling of animals-Dairy cattle. Accessed July 12, 2015. http://www.nfacc.ca/codes-of-practice/dairy-cattle/code.

Nauta, W. J., R. F. Veerkamp, E. W. Brascamp, and H. Bovenhuis. 2006. Genotype by environment interaction for milk production traits between organic and conventional dairy cattle production in The Netherlands. J. Dairy Sci. 89:2729-2737.

Neves, R. C., K. E. Leslie, J. S. Walton, and S. J. LeBlanc. 2012. Reproductive performance with an automated activity monitoring system versus a synchronized breeding program. J. Dairy Sci. 95:5683-5693.

Noordhuizen, J. P. T. M., M. J. van Egmond, R. Jorritsma, H. Hogeveen, T. van Werven, P. L. Vos, and J. J. Lievaart. 2008. Veterinary advice for entrepreneurial Dutch dairy farmers: From curative practice to coach-consultant: What needs to be changed? Tijdschr. Diergeneeskd. 133:4-8.

Norman, H. D., J. L. Hutchison, and R. H. Miller. 2010. Use of sexed semen and its effects on conception rate, calf sex, dystocia, and stillbirth of Holsteins in the United States. J. Dairy Sci. 93:38803890 .

Olde Riekerink, R. G. M., H. W. Barkema, D. F. Kelton, and D. T. Scholl. 2008. Incidence rate of clinical mastitis on Canadian dairy farms. J. Dairy Sci. 91:1366-1377.

Oliveira, L., and P. L. Ruegg. 2014. Treatments of clinical mastitis occurring in cows on 51 large dairy herds in Wisconsin. J. Dairy Sci. 97:5426-5436

Ontario Medical Association. 2013. When antibiotics stop working. Accessed July 12, 2015. https://www.oma.org/Resources/Documents/Antibiotics03192013.pdf

Popescu, S., C. Borda, E. A. Diugan, M. Spinu, I. S. Groza, and C. D. Sandru. 2013. Dairy cows' welfare quality in tie-stall housing system with or without access to exercise. Acta Vet. Scand. 55:43.

Prescott, J. F. 2014. The resistance tsunami, antimicrobial stewardship, and the golden age of microbiology. Vet. Microbiol. 171:273278 .

Progressive Dairy Operators. 2013. 2013 Dairy farm labour and calf management survey. Accessed July 12, 2015. http://www.lhoontario.ca/PDF/PDO\% 20labour\% 20 survey\% 20 info\% 20 for $\% 20$ tour\%20_2_.pdf.

Raaperi, K., T. Orro, and A. Viltrop. 2014. Epidemiology and control of bovine herpesvirus 1 infection in Europe. Vet. J. 201:249-256.

Radtke, A., T. Bruheim, J. E. Afset, and K. Bergh. 2012. Multiplelocus variant-repeat assay (MLVA) is a useful tool for molecular epidemiologic analysis of Streptococcus agalactiae strains causing bovine mastitis. Vet. Microbiol. 157:398-404.

Raymond, M. J., R. D. Wohrle, and D. R. Call. 2006. Assessment and promotion of judicious antibiotic use on dairy farms in Washington State. J. Dairy Sci. 89:3228-3240.

Reyher, K. K., S. Dufour, H. W. Barkema, L. Des Côteaux, T. J. Devries, I. R. Dohoo, G. P. Keefe, J.-P. Roy, and D. T. Scholl. 2011. The National Cohort of Dairy Farms - A data collection platform for mastitis research in Canada. J. Dairy Sci. 94:1616-1626.

Richards, T. J., and S. R. Jeffrey. 1997. The effect of supply management on herd size in Alberta dairy. Am. J. Agric. Econ. 79:555565.

Richert, R. M., K. M. Cicconi, M. J. Gamroth, Y. H. Schukken, K. E. Stiglbauer, and P. L. Ruegg. 2013. Risk factors for clinical mastitis, ketosis, and pneumonia in dairy cattle on organic and small conventional farms in the United States. J. Dairy Sci. 96:4269-4285.

Roesch, M., M. G. Doherr, and J. W. Blum. 2005. Performance of dairy cows on Swiss farms with organic and integrated production. J. Dairy Sci. 88:2462-2475.

Rossmanith, W., M. Deinhofer, R. Janacek, R. Trampler, and E. Wilhelm. 2010. Voluntary and compulsory eradication of bovine viral diarrhoea virus in Lower Austria. Vet. Microbiol. 142:143-149.

Ruegg, P. L. 2009. Management of mastitis on conventional and organic farms. J. Anim. Sci. 87(Suppl.):43-55.

Rutherford, K. M. D., F. M. Langford, M. C. Jack, L. Sherwood, A. B. Lawrence, and M. J. Haskell. 2008. Hock injury prevalence and associated risk factors on organic and nonorganic dairy farms in the United Kingdom. J. Dairy Sci. 91:2265-2274.

Rutherford, K. M. D., F. M. Langford, M. C. Jack, L. Sherwood, A. B. Lawrence, and M. J. Haskell. 2009. Lameness prevalence and risk factors in organic and non-organic dairy herds in the United Kingdom. Vet. J. 180:95-105.

Rutten, C. J., W. Steeneveld, C. Inchaisri, and H. Hogeveen. 2014. An ex ante analysis on the use of activity meters for automated estrus detection: To invest or not to invest? J. Dairy Sci. 97:6869-6887.

Rutten, C. J., A. G. J. Velthuis, W. Steeneveld, and H. Hogeveen. 2013. Invited review: Sensors to support health management on dairy farms. J. Dairy Sci. 96:1928-1952.

Sahlström, L., T. Virtanen, J. Kyyrö, and T. Lyytikäinen. 2014. Biosecurity on Finnish cattle, pig and sheep farms-Results from a questionnaire. Prev. Vet. Med. 117:59-67.

Saini, V., J. T. McClure, D. Léger, S. Dufour, A. G. Sheldon, D. T. Scholl, and H. W. Barkema. 2012a. Antimicrobial use on Canadian dairy farms. J. Dairy Sci. 95:1209-1221.

Saini, V., J. T. McClure, D. Léger, G. P. Keefe, D. T. Scholl, D. M. Morck, and H. W. Barkema. 2012c. Antimicrobial resistance profiles of common mastitis pathogens on Canadian dairy farms. J. Dairy Sci. 95:4319-4332.

Saini, V., J. T. McClure, D. T. Scholl, T. J. De Vries, and H. W. Barkema. 2012b. Herd-level association between antimicrobial use and antimicrobial resistance in bovine mastitis Staphylococcus aureus isolates on Canadian dairy farms. J. Dairy Sci. 95:1921-1929.

Saint-Dizier, M., and S. Chastant-Mallard. 2012. Towards an automated detection of oestrus in dairy cattle. Reprod. Domest. Anim. 47:1056-1061.

Sandahl, C., H. Gustafsson, C. J. Wallin, L. Meurling, J. Øvretveit, M. Brommels, and J. Hansson. 2013. Simulation team training for improved teamwork in an intensive care unit. Int. J. Health Care Qual. Assur. 26:174-188.

Sarrazin, S., A. B. Cay, J. Laureyns, and J. Dewulf. 2014. A survey on biosecurity and management practices in selected Belgian cattle farms. Prev. Vet. Med. 117:129-139.

Sayers, R. G., J. P. Sayers, J. F. Mee, M. Good, M. L. Bermingham, J. Grant, and P. G. Dillon. 2013. Implementing biosecurity measures on dairy farms in Ireland. Vet. J. 197:259-267.

Schenker, M., and P. Gunderson. 2013. Occupational health in the dairy industry needs to focus on immigrant workers, the new normal. J. Agromedicine 18:184-186.

Scherpenzeel, C. G. M., I. E. M. den Uijl, G. van Schaik, R. G. M. Olde Riekerink, J. M. Keurentjes, and T. J. G. M. Lam. 2014. Evaluation of the use of dry cow antibiotics in low somatic cell count cows. J. Dairy Sci. 97:3606-3614.

Schuenemann, G. M., S. Bas, E. Gordon, and J. D. Workman. 2013. Dairy calving management: Description and assessment of a training program for dairy personnel. J. Dairy Sci. 96:2671-2680.

Schuppli, C. A., M. A. G. von Keyserlingk, and D. M. Weary. 2014. Access to pasture for dairy cows: Responses from an on-line engagement. J. Anim. Sci. 92:5185-5192.

Seidel, G. E. 2014. Update on sexed semen technology in cattle. Animal 8(Suppl. 1):160-164.

Sepúlveda-Varas, P., D. M. Weary, and M. A. von Keyserlingk. 2014. Lying behavior and postpartum health status in grazing dairy cows. J. Dairy Sci. 97:6334-6343. 
Shahid, M. Q., J. K. Reneau, H. Chester-Jones, R. C. Chebel, and M. I. Endres. 2015. Cow- and herd-level risk factors for on-farm mortality in Midwest US dairy herds. J. Dairy Sci. 98:4401-4413.

Sibbald, B. J. 2012. Farm-grown superbugs: While the world acts, Canada dawdles. CMAJ 184:1553.

Simensen, E., O. Østerås, K. E. Bøe, C. Kielland, L. E. Ruud, and G. Naess. 2010. Housing system and herd size interactions in Norwegian dairy herds; associations with performance and disease incidence. Acta Vet. Scand. 52:14.

Sinclair, K., A. Curtis, E. Mendham, and M. Mitchell. 2014. Can resilience thinking provide useful insights for those examining efforts to transform contemporary agriculture? Agric. Human Values $31: 371-384$.

Sogstad, Å. M., T. Fjeldaas, O. Østerås, and K. Plym Forshell. 2005. Prevalence of claw lesions in Norwegian dairy cattle housed in tie stalls and free stalls. Prev. Vet. Med. 70:191-209.

Speksnijder, D. C., D. J. Mevius, C. J. Bruschke, and J. A. Wagenaar. 2015. Reduction of veterinary antimicrobial use in The Netherlands. The Dutch success model. Zoonoses Public Health 62(Suppl 1):79-87.

Spooner, J. M., C. A. Schuppli, and D. Fraser. 2014. Attitudes of Canadian citizens toward farm animal welfare: A qualitative study. Livest. Sci. 163:150-158.

Susanto, D., C. P. Rosson, D. P. Anderson, and F. J. Adcock. 2010. Immigration policy, foreign agricultural labor, and exit intentions in the United States dairy industry. J. Dairy Sci. 93:1774-1781.

Sutherland, M. A., and C. B. Tucker. 2011. The long and short of it: A review of tail docking in farm animals. Appl. Anim. Behav. Sci. 135:179-191.

Svendsen, M., and I. M. A.-Ranberg. 2000. Genetic evaluation for functional traits in Norway. Interbull Bull. 25:135-138.

Svensson, C., and M. B. Jensen. 2007. Identification of diseased calves by use of data from automatic milk feeders. J. Dairy Sci. 90:994997.

Svensson, C., and P. Liberg. 2006. The effect of group size on health and growth rate of Swedish dairy calves housed in pens with automatic milk-feeders. Prev. Vet. Med. 73:43-53.

Swensson, C. 2008. Towards loose housing in Swedish organic dairy production. Pages 122-125 in Proc. 2nd Scientific Conference of the International Society of Organic Agricultural Research, June16-20, Modena, Italy. International Society of Organic Agriculture Research, Trenthorst, Germany.

Te Velde, H., N. Aarts, and C. Van Woerkum. 2002. Dealing with ambivalence: Farmers' and consumers' perceptions of animal welfare in livestock breeding. J. Agric. Environ. Ethics 15:203-219.

Tenhagen, B. A., B. Vossenkuhl, A. Käsbohrer, K. Alt, B. Kraushaar, B. Guerra, A. Schroeter, and A. Fetsch. 2014. Methicillinresistant Staphylococcus aureus in cattle food chains-Prevalence, diversity, and antimicrobial resistance in Germany. J. Anim. Sci. 92:2741-2751.

Thompson-Crispi, K., H. Atalla, F. Miglior, and B. A. Mallard. 2014a. Bovine mastitis: Frontiers in immunogenetics. Front. Immunol. 5:493.

Thompson-Crispi, K. A., M. Sargolzaei, R. Ventura, M. Abo-Ismail, F. Miglior, F. Schenkel, and B. A. Mallard. 2014b. A genome-wide association study of immune response traits in Canadian Holstein cattle. 2014. BMC Genomics 15:559.

Thompson-Crispi, K. A., A. Sewalem, F. Miglior, and B. A. Mallard. 2012. Genetic parameters of adaptive immune response traits in Canadian Holsteins. J. Dairy Sci. 95:401-409.

USDA. 2007. Dairy 2007, Part I: Reference of dairy cattle health and management practices in the United States, 2007. USDA-APHISVS, CEAH. Fort Collins, CO, USA, \#N480.1007. Accessed July 12 , 2015. http://www.aphis.usda.gov/animal_health/nahms/ dairy/downloads/dairy07/Dairy07_dr_PartI.pdf.

USDA. 2010. Biosecurity practices on U.S. dairy operations, 19912007. USDA-APHIS-VS, CEAH. Fort Collins, CO, USA, \#544.0510. Accessed July 12, 2015. http://www.aphis.usda.gov/ animal_health/nahms/dairy/downloads/dairy07/Dairy07_ir_ Biosecurity.pdf.
USDA-NASS. 1999. Milk cows and production-Final estimates 19931997. Statistical Bulletin No. 960. USDA-NASS, Washington, DC USDA-NASS. 2013a. Milk production. USDA-NASS, Washington, DC.

USDA-NASS. 2013b. Livestock-Historical track records. USDANASS, Washington, DC.

USDA-NASS. 2013c. Farms, land in farms and livestock operations. USDA-NASS, Washington, DC.

Valde, J. P., D. W. Hird, M. C. Thurmond, and O. Østerås. 1997. Comparison of ketosis, clinical mastitis, somatic cell count, and reproductive performance between free stall and tie stall barns in Norwegian dairy herds with automatic feeding. Acta Vet. Scand. 38:181-192.

Valle, P. S., E. Skjerve, S. W. Martin, R. B. Larssen, O. Østerås, and O. Nyberg. 2005. Ten years of bovine viral diarrhoea virus (BVDV) control in Norway: A cost-benefit analysis. Prev. Vet. Med. 72:189-207.

van der Spek, D., J. A. M. van Arendonk, and H. Bovenhuis. 2015. Genome-wide association study for claw disorders and trimming status in dairy cattle. J. Dairy Sci. 98:1286-1295.

van Doormaal, B. 2011. Value of DHI: Today and in the future. Accessed July 12, 2015. www.cdn.ca/document.php?id=235.

van Engelen, E., N. Schotten, B. Schimmer, J. L. Hautvast, G. van Schaik, and Y. T. van Duijnhoven. 2014. Prevalence and risk factors for Coxiella burnetii (Q fever) in Dutch dairy cattle herds based on bulk tank milk testing. Prev. Vet. Med. 117:103-109.

van Schaik, G., Y. H. Schukken, M. Nielen, A. A. Dijkhuizen, H. W. Barkema, and G. Benedictus. 2002. Probability of and risk factors for introduction of infectious diseases into Dutch SPF dairy farms: A cohort study. Prev. Vet. Med. 54:279-289.

Vanhonacker, F., W. Verbeke, E. Van Poucke, and F. A. Tuyttens, 2007. Segmentation based on consumers' perceived importance and attitude toward farm animal welfare. Int. J. Soc. Food Agric. 15:91-101.

Vanhonacker, F., W. Verbeke, E. Van Poucke, and F. A. Tuyttens. 2008. Do citizens and farmers interpret the concept of farm animal welfare differently? Livest. Sci. 116:126-136.

Vasseur, E., F. Borderas, R. I. Cue, D. Lefebvre, D. Pellerin, J. Rushen, K. M. Wade, and A. M. de Passille. 2010. A survey of dairy calf management practices in Canada that affect animal welfare. J. Dairy Sci. 93:1307-1315.

Veldhuis, A. M., I. M. Santman-Berends, J. M. Gethmann, M. H. Mars, L. van Wuyckhuise, P. Vellema, M. Holsteg, D. HörethBöntgen, F. J. Conraths, and G. van Schaik. 2014. Schmallenberg virus epidemic: Impact on milk production, reproductive performance and mortality in dairy cattle in the Netherlands and Kleve district, Germany. Prev. Vet. Med. 116:412-422.

Ventura, B. A., M. A. von Keyserlingk, C. A. Schuppli, and D. M. Weary. 2013. Views on contentious practices in dairy farming: The case of early cow-calf separation. J. Dairy Sci. 96:6105-6116.

von Keyserlingk, M. A. G., A. Barrientos, K. Ito, E. Galo, and D. M. Weary. 2012. Benchmarking cow comfort on North American freestall dairies: Lameness, leg injuries, lying time, facility design and management, for high-producing Holstein dairy cows. J. Dairy Sci. 95:7399-7408.

von Keyserlingk, M. A., N. P. Martin, E. Kebreab, K. F. Knowlton, R. J. Grant, M. Stephenson, C. J. Sniffen, J. P. Harner III, A. D. Wright, and S. I. Smith. 2013. Invited review: Sustainability of the US dairy industry. J. Dairy Sci. 96:5405-5425.

von Keyserlingk, M. A., J. Rushen, A. M. de Passillé, and D. M. Weary. 2009. Invited review: The welfare of dairy cattle - Key concepts and the role of science. J. Dairy Sci. 92:4101-4111.

von Keyserlingk, M. A. G., and M. J. Hötzel. 2015. The ticking clock Addressing farm animal welfare in emerging countries. J. Agric. Environ. Ethics 28:179-195.

von Keyserlingk, M. A. G., and D. M. Weary. 2010. Review: Feeding behaviour of dairy cattle: Measures and applications. Can. J. Anim. Sci. 90:303-309.

Wagner, S., and R. Erskine. 2006. Antimicrobial drug use in bovine mastitis. Page 511 in Antimicrobial therapy in veterinary medi- 
cine. S. Giguère, J. F. Prescott, J. D. Baggot, R. D. Walker, and P. M. Dowling, ed. Iowa State University Press, Ames.

Walter, K. 1995. Development of costs for veterinary services in intensive dairy farming. 1. General developments and consequences. Prakt. Tierarzt 76:546-551.

Weary, D. M., C. A. Schuppli, and M. A. G. von Keyserlingk. 2011. Tail docking dairy cattle: Responses from an online engagement. J. Anim. Sci. 89:3831-3837.

Wilson, P. 2011. Decomposing variation in dairy profitability: The impact of output, inputs, prices, labour and management. J. Agric. Sci. 149:507-517.

Wiltbank, M. C., and J. R. Pursley. 2014. The cow as an induced ovulator: Timed AI after synchronization of ovulation. Theriogenology 81:170-185.

Winsten, J. R., C. D. Kerchner, A. Richardson, A. Lichau, and J. M. Hyman. 2010. Trends in the Northeast dairy industry: Large-scale modern confinement feeding and management-intensive grazing. J. Dairy Sci. 93:1759-1769.

Wolf, C. A. 2003. The economics of dairy production. Vet. Clin. North Am. Food Anim. Pract. 19:271-293.

Wolf, R., H. W. Barkema, J. De Buck, M. Slomp, J. Flaig, D. Haupstein. C. Pickel, and K. Orsel. 2014a. High herd-level prevalence of Mycobacterium avium subspecies paratuberculosis in Western Canadian dairy herds, based on environmental sampling. J. Dairy Sci. 97:6250-6259.

Wolf, R., F. Clement, H. W. Barkema, and K. Orsel. 2014b. Economic evaluation of participation is a voluntary Johne's disease prevention and control program from a farmer's perspective - The Alberta Johne's Disease Initiative. J. Dairy Sci. 97:2822-2834.
Wolf, R., K. Orsel, J. de Buck, and H. W. Barkema. 2015. Calves shedding Mycobacterium avium subspecies paratuberculosis are common on infected dairy farms. Vet. Res. 46:71.

World Health Organization. 2012. The evolving threat of antimicrobial resistance - Options for action. WHO Press, Geneva Switzerland. Accessed July 12, 2015. http://whqlibdoc.who.int/ publications/2012/9789241503181_eng.pdf.

Young, I., S. Hendrick, S. Parker, A. Rajic, J. T. McClure, J. Sanchez, and S. A. McEwen. 2010. Knowledge and attitudes towards food safety among Canadian dairy producers. Prev. Vet. Med. 94:65-76.

Zaffino Heyerhoff, J. C., S. J. LeBlanc, T. J. DeVries, C. G. R. Nash, J. Gibbons, K. Orsel, H. W. Barkema, L. Solano, J. Rushen, A. M. de Passillé, and D. B. Haley. 2014. Prevalence of, and factors associated with, hock, knee, and neck injuries on dairy cows in freestall housing in Canada. J. Dairy Sci. 97:173-184.

Ziegler, D. M., and H. Chester-Jones. 2013. What we have learned using a computer calf feeder for both milk and grain at the University of Minnesota Southern Research and Outreach Center (SROC) in Waseca. Pages 175-176 in Proc. Precision Dairy Conf. and Expo, Rochester, MN. Accessed Jul. 12, 2015. http://www.precisiondairyfarming.com/2015/wp-content/ uploads/2015/08/2013-Precision-Dairy-Proceedings.pdf.

Zwald, A. G., P. L. Ruegg, J. B. Kaneene, L. D. Warnick, S. J. Wells, C. Fossler, and L. W. Halbert. 2004. Management practices and reported antimicrobial usage on conventional and organic dairy farms. J. Dairy Sci. 87:191-201. 